Aus dem Institut für Molekularbiologie

im Zentrum Biochemie und Molekulare Zellbiologie

(Prof. Dr. B. Schwappach-Pignataro)

der Medizinischen Fakultät der Universität Göttingen

\title{
Cysteine residues of the mammalian GET receptor: Essential for tail-anchored protein insertion?
}

\author{
INAUGURAL-DISSERTATION \\ zur Erlangung des Doktorgrades \\ der Medizinischen Fakultät der \\ Georg-August-Universität zu Göttingen
}

vorgelegt von

Moritz Schaefer

aus

Hameln 
Dekan:

\section{Betreuungsausschuss}

Betreuerin:

Ko-Betreuer:

\section{Prüfungskommission}

Referent/in:

Ko-Referent/in:

Drittreferent/in:
Prof. Dr. rer. nat. H.K. Kroemer

Prof. Dr. Blanche Schwappach-Pignataro

Prof. Dr. Michael Thumm

Prof. Dr. Blanche Schwappach-Pignataro

Prof. Dr. Michael Thumm

Prof. Dr. Martin Oppermann

Datum der mündlichen Prüfung: 30.05.2017 
Hiermit erkläre ich, die Dissertation mit dem Titel "Cysteine residues of the mammalian GET receptor: Essential for tailanchored protein insertion?" eigenständig angefertigt und keine anderen als die von mir angegebenen Quellen und Hilfsmittel verwendet zu haben.

Göttingen, den

(Unterschrift) 


\section{Contents}

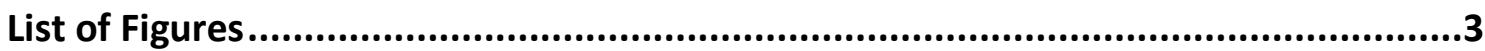

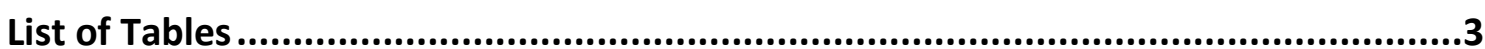

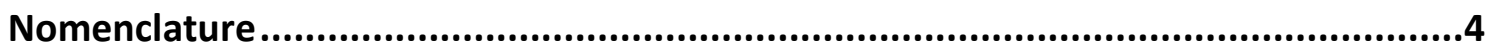

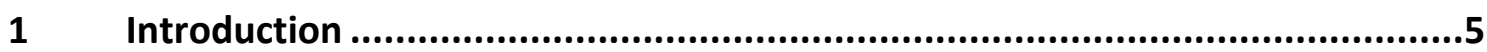

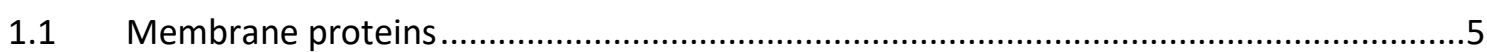

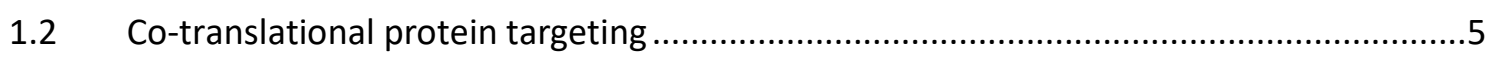

1.3 Post-translational targeting of tail anchored proteins ..............................................

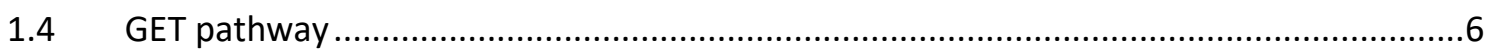

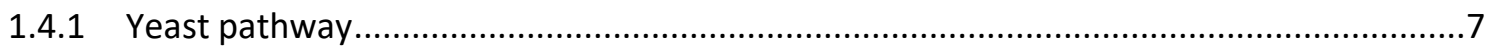

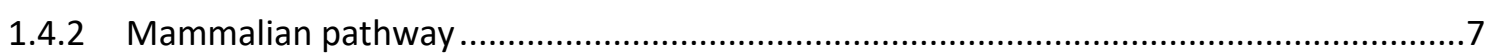

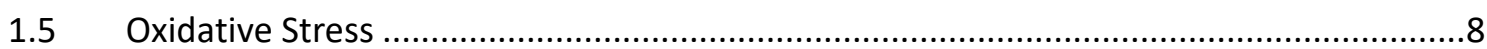

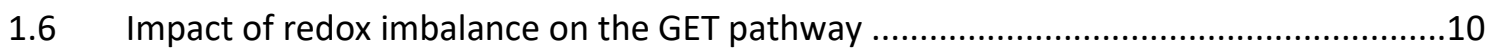

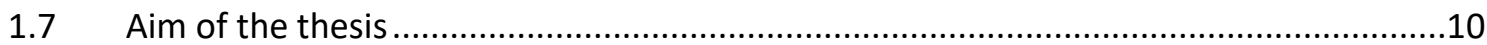

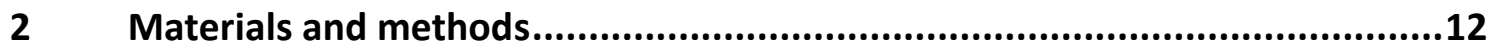

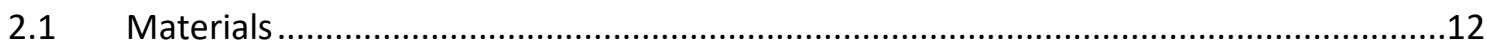

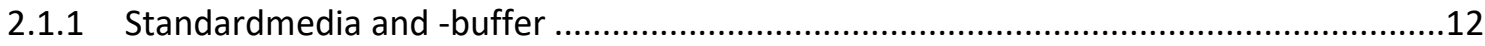

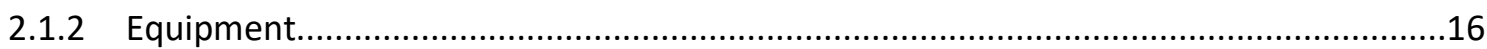

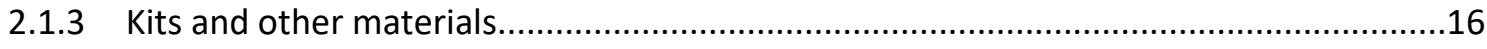

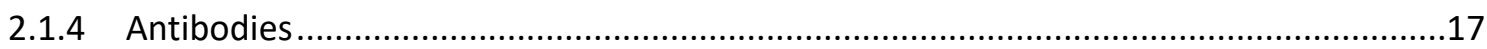

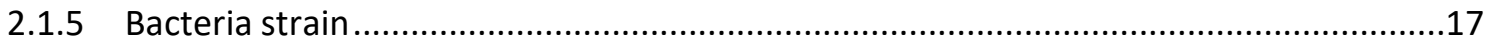

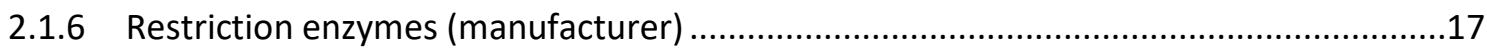

2.1.7 Polymerases and other enzymes (manufacturer) ...................................................18

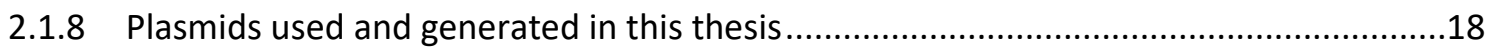

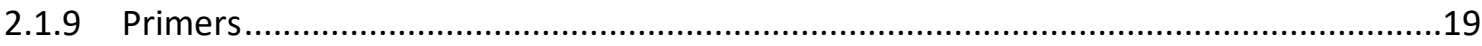

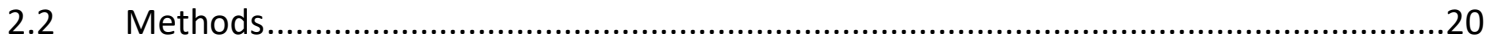

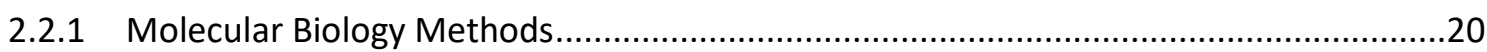

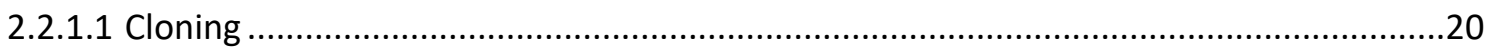

2.2.1.1.1 Quick-Change Mutagenesis Polymerase chain reaction (PCR) ...............................20

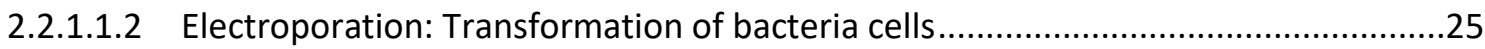

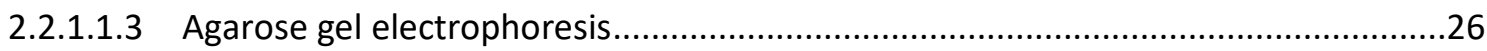

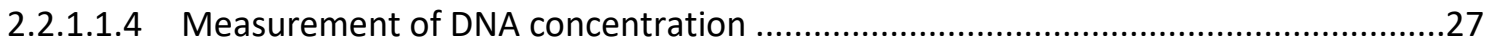

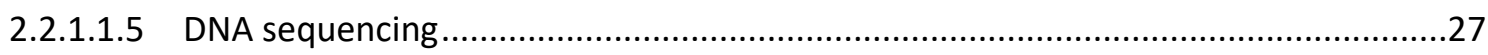

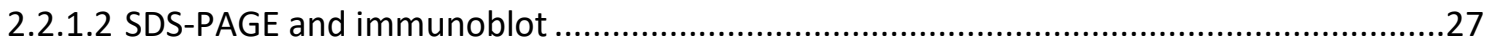

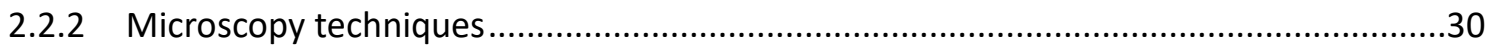

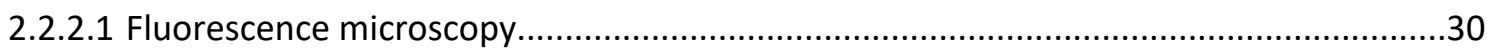

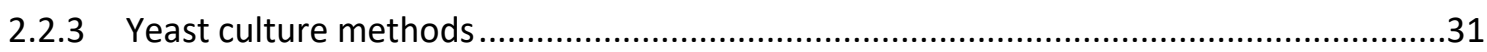

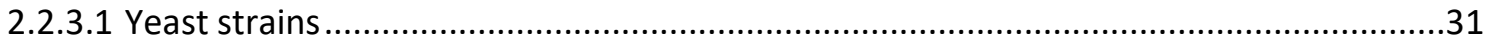




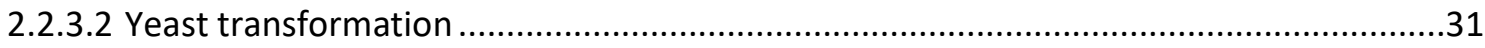

2.2.3.3 Split-ubiquitin yeast two-hybrid assay and spotting .................................................32

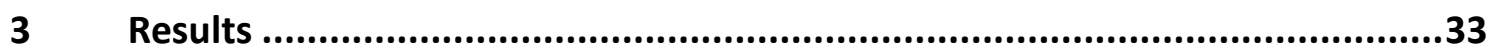

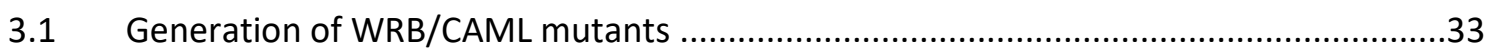

3.2 The role of cysteine residues in the formation of the mammalian GET receptor ...........38

3.3 TA protein membrane insertion by WRB/CAML cysteine mutants ................................41

3.4 Rescue of growth phenotype of $\Delta$ get $1 / 2$ cells ..................................................44

W.5 WRB/CAML under non-reducing conditions .................................................44

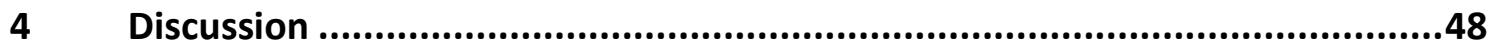

4.1 A cysteine-free variant of the mammalian GET receptor is fully functional in yeast ......48

4.2 Absence of cysteines changes the running behaviour of CAML................................48

4.3 WRB and CAML oligomeric state under non-reducing conditions .............................49

4.4 Do WRB and CAML play a role in cellular redox balance?.....................................50

4.5 Intact cellular chaperone function is a protective factor for health ............................51

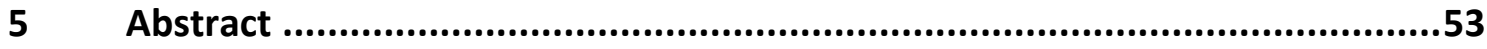

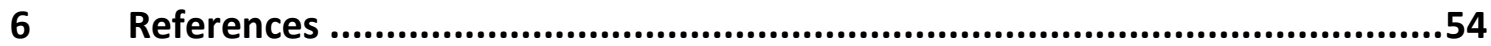




\section{List of Figures}

FIGURE 1: POST-TRANSLATIONAL PROTEIN TARGETING TO THE ER 7

FIGURE 2: LOCATIONS OF CYSTEINES IN WRB AND CAML 11

FIGURE 3: MUTAGENESIS SCHEME

FIGURE 4: WRB AND CAML CONSTRUCTS, C: CYSTEINE POSITION, S: SERINE POSITION 36

FIGURE 5: CAML WESTERN BLOT DETECTION 37

FIGURE 6: SCHEMATIC REPRESENTATION OF THE SPLIT-UBIQUITIN YEAST TWO-HYBRID ASSAY $\begin{array}{ll}\text { WITH WRB WILDTYPE } & 38\end{array}$

FIGURE 7: ROLE OF CYSTEINE RESIDUES IN CAML FOR ITS INTERACTION WITH WRB 39

FIGURE 8: ROLE OF CYSTEINE RESIDUES IN CAML AND CYSTEINES RESIDUES 157 AND 162 OF WRB IN THE FORMATION OF A HETEROOLIGOMER 40

FIGURE 9: CYSTEINE-FREE VARIANTS OF WRB AND CAML ARE NOT IMPAIRED IN THEIR ABILITY TO FORM A HETEROOLIGOMER 41

FIGURE 10: SED5 LOCALIZATION SCHEME

FIGURE 11: SED5 TARGETING 42

FIGURE 12: WRB AND CAML FULL MUTANTS RESCUE THE GROWTH PHENOTYPES OF

$\triangle G E T 1 / G E T 2$ CELLS 43

FIGURE 13: YEAST PROTEIN LYSATE BLOTS UNDER REDUCING/NONREDUCING CONDITIONS 46

\section{List of Tables}

TABLE 1: STANDARDMEDIA AND -BUFFER 12

TABLE 2: EQUIPMENT 16

TABLE 3: ANTIBODIES

TABLE 4: PLASMIDS 18

TABLE 5: PRIMERS $\quad 19$

TABLE 6: PCR REACTION MIXTURE 22

TABLE 7: PCR STEPS 22

TABLE 8: ANNEALING STEPS

TABLE 9: RESTRICTION DIGESTION 24

TABLE 10: LIGATION 25

TABLE 11: POLYACRYLAMIDE GELS 28 


\section{Nomenclature}

\section{Nucleotides}

\begin{tabular}{lll} 
Character & Base & Nucleotide's Group \\
\hline A & Adenine & Purine \\
G & Guanine & Purine \\
U & Uracil & Pyrimidine \\
T & Thymine & Pyrimidine \\
C & Cytosine & Pyrimidine
\end{tabular}

\section{Abbreviations}

Abbreviation

ADP

ATP

$\mathrm{BF}$

C-

CAML

dNTP

DTT

ER

For

GET

GFP

HA

Hsp

$\mathrm{N}-$

OD

Rev

ROS

SNARE

SPRINP

SRP

TA

TMD

WRB
Meaning

Adenosine diphosphate

Adenosine triphosphate

Bright field

Carboxy-

Calcium modulating ligand

Deoxynucleoside triphosphate

Dithiothreitol

Endoplasmic reticulum

Forward

Guided entry of tail-anchored protein insertion

Green fluorescent protein

Human influenza hemagglutinin

Heat shock protein

Amino-

Optical density

Reverse

Reactive oxygen species

Soluble NSF attachment protein receptor

Two single primer reactions in parallel

Signal recognition particle

Tail-anchored

Transmembrane domain

Tryptophan-rich basic protein 


\section{Introduction}

\subsection{Membrane proteins}

Biological membranes are essential for life. They allow marking a border between intraand extracellular space as well as intracellular compartmentalization that enables the eukaryotic cell to fulfil different functions in different microenvironments due to specific ion and protein compositions in each compartment defined by the endomembrane system (Alberts et al. 2011).

Diverse cell types show a big variety of shapes regarding natural membranes. From an erythrocyte's smooth and flexible cell membrane to more rigid membranes like in epidermis cells, there is a wide range of membranes having specific characteristics (Lodish et al. 2012).

However, all membranes have a similar basic structure: they consist of a $5 \mathrm{~nm}$ thick double lipid layer and lipid-associated proteins. The bilayer per se is impermeable to water-solutes like sugars, salts und most other small hydrophilic molecules including water itself. The membrane is stabilized by hydrophobic and van der Waals interactions between the fatty acyl chains (Lodish et al. 2012).

Membrane characteristics are defined by different parameters. Two important parameters are lipid composition and types of proteins in membranes. Targeting of membrane proteins can happen in a co- or post-translational manner. While cotranslationally targeted proteins reach the ER membrane during translation at the ribosome, post-translationally targeted proteins arrive there afterwards. Both types are embedded in membranes by hydrophobic, often $\alpha$-helical sequences called transmembrane domains (TMDs).

\subsection{Co-translational protein targeting}

Most membrane proteins are co-translationally targeted to the ER. This is achieved by recognition of a hydrophobic sequence by the signal recognition particle (SRP) which docks near the nascent chain exit tunnel on the ribosome and binds $\mathrm{N}$-terminal signal sequences. It causes recruitment to the ER membrane where the nascent chain then 
translocates into the ER lumen through a protein channel called translocon. Simultaneously, the TMDs partition into the lipid layer (Rapoport 2007).

\subsection{Post-translational targeting of tail anchored proteins}

About $5 \%$ of membrane proteins are so called tail-anchored (TA) proteins characterized by a single TMD near the C-terminus containing targeting information for the ER membrane.

Functionally diverse TA proteins can be found in different organelles of eukaryotes: in the mitochondrial and chloroplast outer membrane, peroxisomes, endoplasmic reticulum, Golgi apparatus, plasma membrane, endosomes and lysosomes. The larger $\mathrm{N}$-terminal region always faces the cytosol and is responsible for the protein's function (Rabu et al. 2009).

More than 400 TA proteins are encoded by the human genome. Important examples are SNARE (Soluble NSF Attachment Protein Receptor) proteins mediating vesicle fusion and the $\mathrm{Bcl}-2$ protein family, which plays a role in release of apoptotic factors. Other TA proteins are RAMP4 (Ribosome-Associated Membrane Protein 4), Sec61 $\beta$ and Sec61 $\gamma$, components of the translocon complex at the ER membrane (Kalbfleisch et al. 2007).

\subsection{GET pathway}

Although redundant pathways exist, many TA proteins can be post-translationally targeted to the ER membrane by the guided-entry of TA protein insertion (GET) pathway.

These protein's hydrophobic TMDs are not shielded by the SRP like co-translationally targeted membrane proteins because they stay in the ribosomal tunnel until the end of translation. The GET pathway provides its own mechanism to prevent them from forming cytosolic protein aggregates (Wang et al. 2011). 


\subsubsection{Yeast pathway}

After the TA protein is translated and then released from the ribosome, the C-terminal TMD is immediately shielded by Sgt2, a protein in complex with Get4 and Get5, cytosolic members of the GET pathway (Kohl et al. 2011). An ATP-bound form of Get3 interacts with Get4 and this step allows the binding of TA proteins to Get3 (Wang et al. 2011). The proteins Get1 and Get2 compose the receptor for Get3 at the ER membrane. They interact via their TMDs and Get2 individually captures Get3-TA (Get3 loaded with TA protein) with a tether from the cytosol. Afterwards the Get1 cytosolic domain binds to

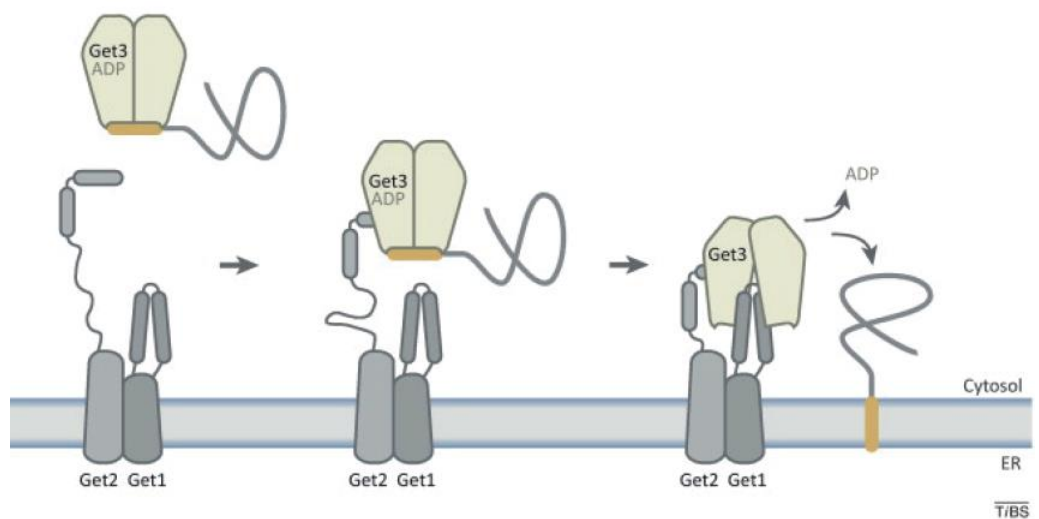

Figure 1: Post-translational protein targeting to the ER (Denic 2012)
Get3-TA causing substrate release and helping integration into the ER membrane.

Get3 and thereby the whole pathway uses an ATP cycle where ATPhydrolysis provides the energy required for membrane integration of TA proteins, whereas binding of new ATP may be required for dissociation of Get3 from the membrane receptor resetting the GET pathway (Mariappan et al. 2011; Stefer et al. 2011).

\subsubsection{Mammalian pathway}

In mammals Bag6, a protein not conserved in yeast, captures newly synthesized TA proteins. Bag6 binds the ribosome while it is in complex with yeast homologs of Get4 and Get5, Ubl4A and TRC35. Now the TA protein is transferred to TRC40 and therefore it is not ribosome-associated anymore. WRB (tryptophan-rich basic protein) works as a TRC40 receptor at the ER membrane. It shows weak sequence homology and similar predicted topology to Get1 (Schuldiner et al. 2008; Vilardi et al. 2011).

WRB interacts with another ER membrane protein, CAML (calcium-signal modulating cyclophilin ligand). CAML does not show sequence similarity to Get2 but is functionally 
equivalent and together with WRB it forms the mammalian TRC40 receptor (Yamamoto und Sakisaka 2012; Vilardi et al. 2014).

CAML plays a role in calcium mobilization as well as in development and survival of peripheral follicular B and T cells (Bram und Crabtree 1994; Zane et al. 2012). It also mediates membrane trafficking by binding gamma-amino butyric acid $A\left(G A B A_{A}\right)$ receptors (Yuan et al. 2008). Tissue-specific knockout in the mouse inner ear causes deafness but the global knockout is lethal in early embryonic development stages (Tran et al. 2003; Bryda et al. 2012).

Both proteins, WRB and CAML, contain three TMDs. The TMDs of CAML are crucial for the interaction between both proteins and the receptor function (Vilardi et al. 2014).

Cysteine residues are located in most of the TMDs in WRB and CAML but it is not known yet if they are significant for interaction and function of the receptor. Cysteines can form disulphide bonds within one protein or between different proteins. This has major effects on protein structure and consequently can play a role in protein interaction. Cysteines respond to changes in redox environment. They are sensitive to oxidative stress as reactive oxygen species (ROS) or metal ions can affect the oxidation status of cysteine thiols and the formation of disulphide bonds.

\subsection{Oxidative Stress}

Accumulation of ROS like superoxide, hydrogen peroxide, and hydroxyl radicals causes oxidative stress. Those metabolic side products are produced in all organisms with an aerobic metabolism (Dröse and Brandt 2012). While low levels of ROS impair cell growth, development and differentiation high levels lead to oxidation of proteins, lipids and DNA. The cell protects itself with mechanisms like ROS-detoxifying enzymes, oxidoreductases of the glutaredoxin and thioredoxin systems and glutathione to increase its resistance against redox imbalance (Masip et al. 2006; D’Autréaux and Toledano 2007; Winterbourn 2015; Imlay 2013).

These protection mechanisms lose their function during aging, in neurodegenerative diseases like Parkinson's disease or metabolic diseases like diabetes (Reuter et al. 2009). However, an increase of ROS is also caused by exogenous effects like X-rays, UV-light and gamma rays as well as by pollutants smoke. 
Alzheimer's disease is the most common type of dementia worldwide affecting more than five million people (Selkoe 2012). It is strongly connected with derogation of antioxidant capacity in the neurones, which can be caused by oxidative stress leading to brain damage and cell dysfunction. Alzheimer's disease mostly affects the elderly and one reason for this is increased vulnerability to oxidative stress at older ages (Nunomura et al. 2001). Moreover, oxidative stress causes DNA demethylation and oxidation in gene regions important for Alzheimer's disease. This could be an important mechanism to explain the accumulation of Amyloid- $\beta$, the protein composing senile plaques in the brain (Gu et al. 2013). It was also discovered that oxidative stress impairs neurogenesis in mice (Hamilton and Holscher 2012).

Well-studied and highly prevalent cardiovascular diseases are also strongly connected with ROS and oxidative stress. ROS lead to a loss of nitric oxide bioavailability in the vascular cell wall and therefore to endothelial dysfunction (Harrison 1997; Schächinger and Zeiher 2000).

Diabetes mellitus affects more than 300 million people worldwide by 2015 and this number is even expected to ascend because of lifestyle changes in many developing countries (King et al. 1998). Cardiovascular diseases are the most common cause of death among diabetes patients. In detail, this means they develop coronary artery disease, cardiac hypertrophy or heart failure. What plays a major role in the pathogenesis of these diabetes-related cardiovascular diseases is ROS overproduction during hyperglycaemia (Braunwald 2008). Chronic inflammation and fibrosis in different tissues of the human body are provoked by enduring oxidative stress that is caused by ROS (Zhao et al. 2008). Furthermore, inflammation and oxidative stress lead to $\beta$-cell loss in Diabetes mellitus 1 and 2 (Ma et al. 2010).

Outside influences such as alcohol, drugs, pollutants and irradiation are known to cause oxidative stress in the liver. Reactive oxygen species are responsible for initiation and progression of various liver diseases such as alcoholic liver disease, chronic viral hepatitis and non-alcoholic steatohepatitis. Modulating pathways for stellate cell function, protein expression as well as apoptosis are impaired by oxidative stress (Cichoż-Lach and Michalak 2014). 
These are only some examples for the role of oxidative stress in the pathogenesis of different diseases.

\subsection{Impact of redox imbalance on the GET pathway}

To find out what specific effect oxidative stress can have on the human body, it is important to better understand physiological processes and how perturbations on redox balance can have an effect on cellular pathways.

ROS lead to massive decrease of intracellular ATP levels impairing the functioning of ATP dependent chaperone systems (Leichert et al. 2008). With lower chaperone capacity in the cell, misfolded proteins tend to accumulate because of reduced chaperoning of their hydrophobic domains. This may lead to the formation of cytosolic protein aggregates.

Further mechanisms exist to protect the cell from oxidative stress damage. A recent study discovered an ATP-independent chaperone function of the ATPase Get3 (Voth et al. 2014). This chaperone function of Get3 is distinct from its role in the GET-pathway (Schuldiner et al. 2008). Under oxidative stress conditions, Get3 undergoes a fully reversible transformation: Get3 regions that are buried on the TA protein-targeting active dimer become more exposed and the zinc ion present on the dimer is released. New disulphide bonds are formed. This allows Get3 to form high molecular weight oligomers and among them, the tetramer is the minimal chaperone-active form (Voth et al. 2014). Get3 response to oxidative stress and its cysteine arrangement is reminiscent of Hsp33, a redox-regulated ATP-independent chaperone in bacteria rescuing bacteria cells under oxidative stress conditions. In both proteins $\mathrm{C}-\mathrm{X}-\mathrm{C}-\mathrm{X}_{43}-\mathrm{C}-\mathrm{X}-$ $\mathrm{X}-\mathrm{C}$ motifs are present probably important their redox regulating function (Jakob et al. 1999).

\subsection{Aim of the thesis}

It is known that disulphide bonds play key roles in protein folding, interaction and function. This is why they are a central subject of current redox biochemistry research. Get1 and Get2 do not contain any cysteines while WRB contains three and CAML contains five. For what reason would evolution introduce new cysteines in these proteins? Apart from one cysteine present in the cytosolic domain of CAML, all of them 
are within the transmembrane domains of the proteins. Considering all this together, they might be crucial for the formation of a WRB/CAML heterooligomer and/or for mediating membrane integration of substrate TA proteins. Since Get3 and presumably TRC40 are redox-sensitive components of the GET pathway, it is important to test whether such redox regulation extends to the mammalian GET receptor.

Hence, in this thesis I aim to investigate the role of the cysteine residues in WRB and CAML and to test whether they are essential for tail-anchored protein biogenesis.

Mutants of WRB and CAML in which the cysteine residues were mutated to serine were generated using a site-directed mutagenesis. We used a yeast based complementation assay in which cells lacking the genes encoding Get1 and Get2 were transformed with plasmids encoding either wild type or mutant WRB and CAML. To test the functionality of the receptor we performed fluorescence microscopy to observe targeting of GFPtagged TA protein Sed5.
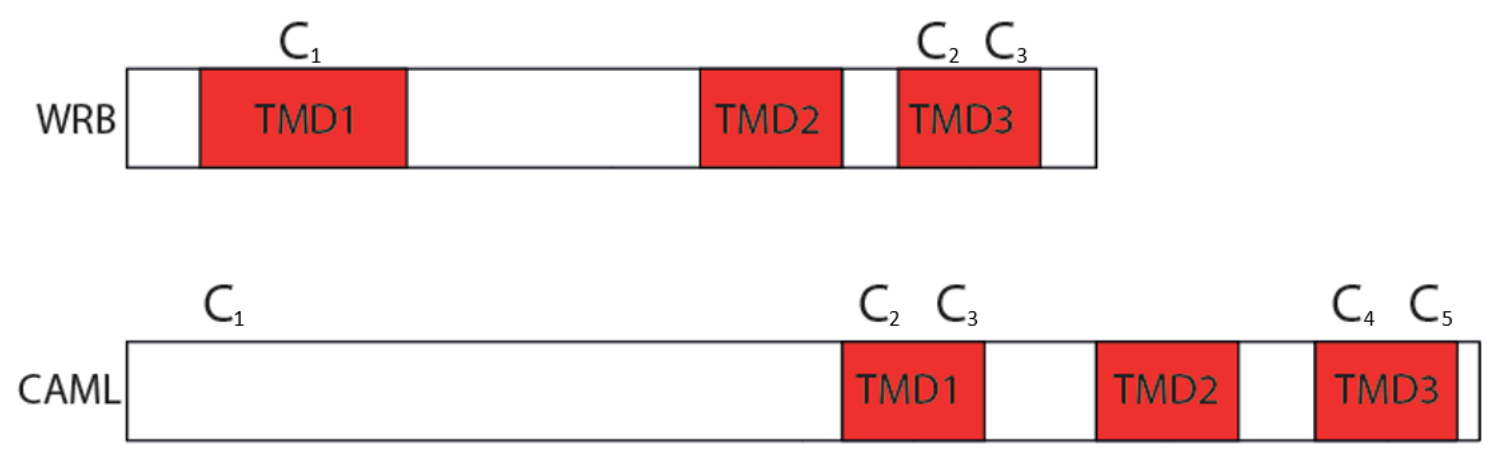

Figure 2: Locations of cysteines in WRB and CAML 


\section{Materials and methods}

\subsection{Materials}

\subsubsection{Standardmedia and -buffer}

Table 1: Standardmedia and -buffer

\begin{tabular}{|c|c|c|}
\hline Name & Concentration & Composition \\
\hline Acrylamide & $30 \%(w / v)$ & $\begin{array}{l}\text { Acrylamide 4K } 292.2 \mathrm{~g} / \mathrm{l} \text {, bisacrylamide } \\
\text { 4K } 7.8 \mathrm{~g} / \mathrm{l}\end{array}$ \\
\hline Ampicillin stock solution & $100 \mathrm{mg} / \mathrm{ml}$ & $\begin{array}{l}\text { Ampicillin-Sodiumsalt in } \mathrm{H}_{2} \mathrm{O} \text {, sterile } \\
\text { filtered, storage at } 20^{\circ} \mathrm{C}\end{array}$ \\
\hline Ammoniumpersulfate $10 \%$ & $10 \%(w / v)$ & Ammoniumpersulfate powder \\
\hline \multirow[t]{2}{*}{ Bacteria agar (LB-Agar) } & $20 \mathrm{~g} / \mathrm{l}$ & Agar in LB medium, autoclaved \\
\hline & $100 \mu \mathrm{g} / \mathrm{ml}$ & Ampicillin \\
\hline \multirow[t]{3}{*}{$\begin{array}{l}\text { Blocking solution for western } \\
\text { blot }\end{array}$} & $1 x$ & TBS in $\mathrm{H}_{2} \mathrm{O}$ \\
\hline & $5 \%(w / v)$ & Milk powder \\
\hline & $0.02 \%(v / v)$ & NP-40 \\
\hline \multirow[t]{2}{*}{ DNA loading buffer $6 X$} & $30 \%(v / v)$ & Glycerol \\
\hline & $0.2 \%(w / v)$ & Bromophenol blue \\
\hline Yeast agar & $40 \mathrm{~g} / \mathrm{l}$ & $\begin{array}{l}\text { Bactoagar for yeast in } \mathrm{H}_{2} \mathrm{O} \text { or YPAD, } \\
\text { autoclaved }\end{array}$ \\
\hline \multirow[t]{5}{*}{ Yeast media YPAD } & $10 \mathrm{~g} / \mathrm{l}$ & Yeast extract \\
\hline & $20 \mathrm{~g} / \mathrm{l}$ & Bacto peptone \\
\hline & $40 \mathrm{mg} / \mathrm{l}$ & Adenine sulfate \\
\hline & $20 \mathrm{~g} / \mathrm{l}$ & Glucose \\
\hline & & $\mathrm{H}_{2} \mathrm{O}$ ad $1 \mathrm{I}$, autoclave \\
\hline
\end{tabular}




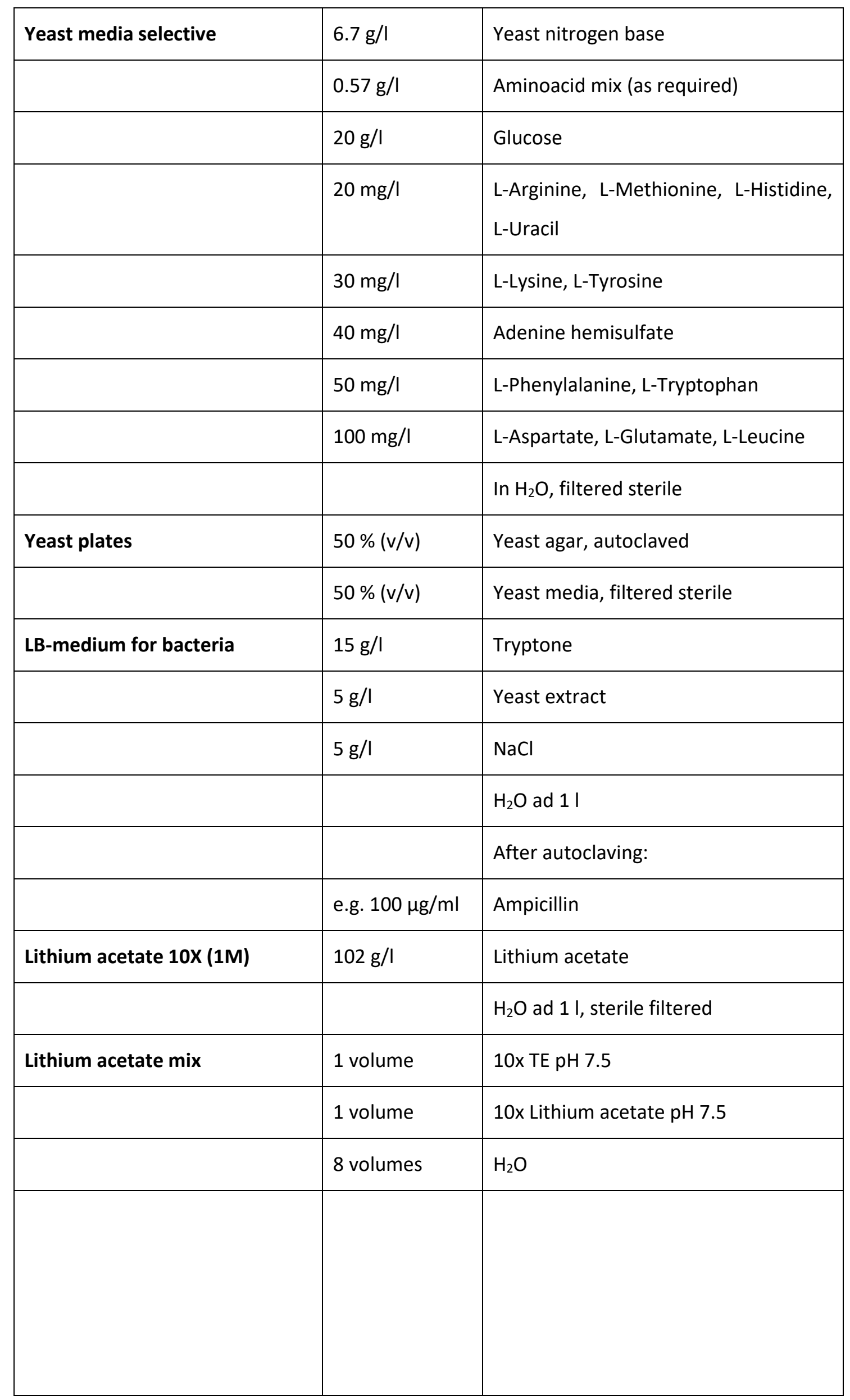




\begin{tabular}{|c|c|c|}
\hline \multirow{4}{*}{$\begin{array}{l}\text { PBS (phosphate buffered saline) } \\
\text { 1X }\end{array}$} & $140 \mathrm{mM}$ & $\mathrm{NaCl}$ \\
\hline & $3 \mathrm{mM}$ & $\mathrm{KCl}$ \\
\hline & $8 \mathrm{mM}$ & $\mathrm{Na}_{2} \mathrm{HPO}_{4} \mathrm{pH} 7.4$ \\
\hline & & $\mathrm{H}_{2} \mathrm{O}$ ad $1 \mathrm{I}$ \\
\hline PEG stock solution (50 \%) & $500 \mathrm{~g} / \mathrm{l}$ & $\begin{array}{l}\text { PEG (polyethylene glycol) } 4000 \text { in } \mathrm{H}_{2} \mathrm{O} \text {, } \\
\text { filtered sterile }\end{array}$ \\
\hline \multirow[t]{3}{*}{ PEG mix } & 8 volumes & $50 \%$ PEG \\
\hline & 1 volume & $10 \times \mathrm{TE} \mathrm{pH} 7.5$ \\
\hline & 1 volume & $10 \times$ Lithium acetate \\
\hline \multirow[t]{4}{*}{ Ponceau-S stock solution 10X } & $20 \mathrm{~g} / \mathrm{l}$ & Ponceau-S \\
\hline & $300 \mathrm{~g} / \mathrm{l}$ & Trichloroacetic acid \\
\hline & $300 \mathrm{~g} / \mathrm{l}$ & Sulfursalicylic acid \\
\hline & & In $\mathrm{H}_{2} \mathrm{O}$ \\
\hline \multirow{5}{*}{$\begin{array}{l}\text { SDS loading buffer protein gel } \\
5 X\end{array}$} & $250 \mathrm{mM}$ & Tris-HCl pH 6.8 \\
\hline & $5 \%(w / v)$ & SDS $10 \%$ \\
\hline & $0.5 \%(w / v)$ & Bromophenol blue \\
\hline & $50 \%(v / v)$ & Glycerol \\
\hline & $250 \mathrm{mM}$ & DTT (Dithiothreitol) \\
\hline \multirow{4}{*}{$\begin{array}{l}\text { SDS running buffer protein gel } \\
5 X\end{array}$} & $250 \mathrm{mM}$ & Glycine $\mathrm{pH} 8.3$ \\
\hline & $125 \mathrm{mM}$ & Tris \\
\hline & $0.1 \%(v / v)$ & $10 \%$ SDS \\
\hline & & $\mathrm{H}_{2} \mathrm{O}$ ad $1 \mathrm{I}$ \\
\hline & & \\
\hline
\end{tabular}




\begin{tabular}{|c|c|c|}
\hline \multirow[t]{2}{*}{ SOC medium for bacteria } & $20 \mathrm{~g} / \mathrm{l}$ & Tryptone \\
\hline & $5 \mathrm{~g} / \mathrm{l}$ & Yeast extract \\
\hline & $0.5 \mathrm{~g} / \mathrm{l}$ & $\mathrm{NaCl}$ \\
\hline & $2.5 \mathrm{mM}$ & $\mathrm{KCl}$ \\
\hline & & $\mathrm{H}_{2} \mathrm{O}$, after autoclaving \\
\hline & $10 \mathrm{mM}$ & $\mathrm{MgCl}_{2}$ \\
\hline & $20 \mathrm{mM}$ & Glucose \\
\hline SDS $10 \%$ & $100 \mathrm{~g} / \mathrm{l}$ & Sodium dodecyl sulfate \\
\hline \multirow[t]{6}{*}{ T4 ligase buffer } & $50 \mathrm{mM}$ & Tris-HCL pH 7.6 \\
\hline & $10 \mathrm{mM}$ & $\mathrm{MgCl}_{2}$ \\
\hline & $1 \mathrm{mM}$ & ATP \\
\hline & $1 \mathrm{mM}$ & DTT \\
\hline & $50 \mathrm{mg} / \mathrm{ml}$ & PEG-8000 \\
\hline & & $\mathrm{H}_{2} \mathrm{O}$, store aliquots at $-20^{\circ} \mathrm{C}$ \\
\hline Trichloroacetic acid (TCA) & $50 \%(w / v)$ & Trichloroacetic acid powder \\
\hline \multirow{3}{*}{$\begin{array}{l}\text { TAE buffer (DNA gel running } \\
\text { buffer) } 20 \mathrm{X}\end{array}$} & $800 \mathrm{mM}$ & Tris-HCL pH 7.5 \\
\hline & $200 \mathrm{mM}$ & Sodium acetate \\
\hline & $20 \mathrm{mM}$ & EDTA pH 8.0 \\
\hline \multirow[t]{3}{*}{ TE $10 \mathrm{X}$} & $100 \mathrm{mM}$ & Tris-HCL pH 7.5 \\
\hline & $10 \mathrm{mM}$ & EDTA \\
\hline & & $\mathrm{pH} 7.5$ with $\mathrm{HCl}$ \\
\hline \multirow[t]{4}{*}{ Transfer buffer $10 \mathrm{X}$} & $390 \mathrm{mM}$ & Glycine \\
\hline & $480 \mathrm{mM}$ & Tris $\mathrm{pH} 8.3$ \\
\hline & $3.7 \mathrm{~g} / \mathrm{l}$ & SDS \\
\hline & & $+20 \%(v / v)$ Methanol in $1 \times$ buffer \\
\hline TBS-Tween 20 & $0.02 \%(v / v)$ & Tween-20 \\
\hline
\end{tabular}




\begin{tabular}{|l|l|l|}
\hline & $1 \times$ & TBS \\
\hline
\end{tabular}

\subsubsection{Equipment}

Table 2: Equipment

\begin{tabular}{|c|c|c|}
\hline & Name & Manufacturer \\
\hline Electroporator & Gene Pulser II & BioRad \\
\hline SDS gel electrophoresis gadget & $\begin{array}{l}\text { Multiple Gel Caster, Mighty } \\
\text { Small } 250\end{array}$ & Hoefer \\
\hline Western blot gadget & $\begin{array}{l}\text { Mighty Small Transfer System } \\
\text { T22 }\end{array}$ & Amersham Biosciences \\
\hline Desk centrifuge, Eppendorf & Biofuge pico & Heraeus \\
\hline Ultra centrifuge & $4 \mathrm{~K} 15$ & Sigma \\
\hline PCR machine & Thermocycler PTC-200 & MJ Research \\
\hline NanoDrop & NanoDrop 2000c & ThermoScientific \\
\hline Western blot detection & Odyssey & Licor \\
\hline $\begin{array}{l}\text { Agarose gel electrophoresis } \\
\text { gadget }\end{array}$ & PowerPac Basic & BioRad \\
\hline Agarose gel detection & GelStick & Intas \\
\hline Spectral photometer & BioMate5 & ThermoScience \\
\hline
\end{tabular}

\subsubsection{Kits and other materials}

\begin{tabular}{|l|l|}
\hline ECL $^{\mathrm{TM}}$ Western Blotting Detection Reagents: & $\begin{array}{l}\text { Amersham Bioscience (catalogue numbers } \\
\text { RPN2106/8/9; RPN2209; RPN2134) }\end{array}$ \\
\hline High Pure PCR Product Purification Kit: & Roche (catalogue number 11732676001) \\
\hline Hybond ${ }^{\mathrm{TM}}-\mathrm{ECL}^{\mathrm{TM}}$ Nitrocellulosemembrane: & $\begin{array}{l}\text { Amersham Bioscience (catalogue number } \\
\text { RPN3032d) }\end{array}$ \\
\hline Nucleo Spin ${ }^{\circledR}$ Plasmid Mini-Kit: & $\begin{array}{l}\text { Machery-Nagel number } \\
740588.250)\end{array}$ \\
\hline
\end{tabular}




\begin{tabular}{|l|l|}
\hline NucleoBond ${ }^{\circledR}$ Xtra Midi-Kit: & $\begin{array}{l}\text { Machery-Nagel (catalogue number } \\
740710.100)\end{array}$ \\
\hline Page Ruler Prestained Protein Ladder: & Thermo Scientific (catalogue number 26616) \\
\hline
\end{tabular}

\subsubsection{Antibodies}

Table 3: Antibodies

\begin{tabular}{|c|c|c|c|c|c|c|}
\hline \multicolumn{7}{|c|}{ Primary antibodies } \\
\hline Antibody & \multicolumn{2}{|c|}{ Specification } & $\begin{array}{l}\text { catalogue } \\
\text { number }\end{array}$ & \multicolumn{2}{|c|}{ Purchased from } & Dilution \\
\hline $\begin{array}{l}\text { anti-HA } \\
\text { epitope }\end{array}$ & \multicolumn{2}{|c|}{ mouse } & H3663 & \multicolumn{2}{|l|}{ Sigma-Aldrich } & $1: 1000$ \\
\hline $\begin{array}{l}\text { alpha-LexA } \\
\text { epitope }\end{array}$ & \multicolumn{2}{|c|}{ rabbit } & $06-719$ & \multicolumn{2}{|l|}{ Millipore } & 1:1000 \\
\hline \multicolumn{7}{|c|}{ Secondary antibodies } \\
\hline \multicolumn{2}{|l|}{ Antibody } & \multicolumn{2}{|c|}{ Catalogue number } & Purchased from & \multicolumn{2}{|l|}{ Dilution } \\
\hline \multicolumn{2}{|c|}{$\begin{array}{l}\text { IRDye 680LT Donkey } \\
\text { anti-Mouse IgG }(\mathrm{H}+\mathrm{L})\end{array}$} & \multicolumn{2}{|c|}{$926-68072$} & LI-COR Biosciences & \multicolumn{2}{|l|}{$1: 5000$} \\
\hline \multicolumn{2}{|c|}{$\begin{array}{l}\text { IRDye 680LT Donkey } \\
\text { anti-Rabbit IgG }(\mathrm{H}+\mathrm{L})\end{array}$} & \multicolumn{2}{|c|}{$926-68073$} & LI-COR Biosciences & \multicolumn{2}{|l|}{$1: 5000$} \\
\hline
\end{tabular}

\subsubsection{Bacteria strain}

DH5- $\alpha$ hdsR17 supE44 $\Delta$ lacU169 (Ф80 lacZ MM15) recA1 endA1 gyrA96 thi 1 rela1 $\Delta$

\subsubsection{Restriction enzymes (manufacturer)}

BamHI, Eco81I, EcoRI, HindIII, Sacll, Sfil, Xbal, Xhol ( Fermentas, New England BioLabs) 


\subsubsection{Polymerases and other enzymes (manufacturer)}

Expand High Fidelity DNA-Polymerase, PCR System, thermostable 3,5 U/ $\mu$ (Roche)

T4-DNA Ligase, 200 CEU/ $\mu$ (Fermentas)

\subsubsection{Plasmids used and generated in this thesis}

The names of plasmids generated in this thesis are depending on the cysteine to serine mutation status. The order of letters corresponds to the order of cysteine/serine within WRB or CAML sequence.

Table 4: Plasmids

\begin{tabular}{|c|c|c|}
\hline Name & Description & Reference \\
\hline p416Met25-WRB & Expression of WRB in S. Cerevisiae & (Vilardi et al. 2014) \\
\hline WRB_SCC & $\begin{array}{l}\text { Expression of WRB in S. Cerevisiae } \\
\text { the mutation was introduced by SPRINP } \\
\text { method in the p416Met } 25-\text { WRB using the } \\
\text { primers } 1 \text { and } 2\end{array}$ & this thesis \\
\hline WRB_CSS & $\begin{array}{l}\text { Expression of WRB in S. Cerevisiae } \\
\text { the mutations were introduced by } \\
\text { mutagenesis PCR in the p416Met } 25-W R B \\
\text { using the primers } 3 \text { and } 4\end{array}$ & this thesis \\
\hline $\begin{array}{l}\text { p415Met25-NubG- } \\
\text { HA-CAML }\end{array}$ & Expression of CAML in S. Cerevisiae & (Vilardi et al. 2014) \\
\hline CAML_SCCCC & $\begin{array}{l}\text { Expression of CAML in S. Cerevisiae } \\
\text { the mutation was introduced by SPRINP } \\
\text { method in the p416Met } 25-\text { WRB using the } \\
\text { primers } 5 \text { and } 6\end{array}$ & this thesis \\
\hline CAML_CSSSS & $\begin{array}{l}\text { Expression of CAML in S. Cerevisiae } \\
\text { the mutations were introduced by } \\
\text { mutagenesis PCR in the CAML wildtype } \\
\text { plasmid using the primers } 7,8,9 \text { and } 10\end{array}$ & this thesis \\
\hline
\end{tabular}




\begin{tabular}{|c|c|c|}
\hline CAML_CCCSS & $\begin{array}{l}\text { Expression of CAML in S. Cerevisiae } \\
\text { the mutations were introduced by cutting } \\
\text { CAML wildtype and CAML_CSSSS with } \\
\text { Eco81I and HindIII(2X) and then ligating }\end{array}$ & this thesis \\
\hline CAML_CSSCC & $\begin{array}{l}\text { Expression of CAML in S. Cerevisiae } \\
\text { the mutations were introduced by cutting } \\
\text { CAML wildtype and CAML_CSSSS with } \\
\text { Eco81I and Xbal and then ligating }\end{array}$ & this thesis \\
\hline CAML_SCCSS & $\begin{array}{l}\text { Expression of CAML in S. Cerevisiae } \\
\text { the mutations were introduced by cutting } \\
\text { CAML_SCCCC and CAML_CSSSS with Eco81I } \\
\text { and HindIII( } 2 \mathrm{X}) \text { and then ligating }\end{array}$ & this thesis \\
\hline CAML_SSSCC & $\begin{array}{l}\text { Expression of CAML in S. Cerevisiae } \\
\text { the mutations were introduced by cutting } \\
\text { CAML_SSSSS and CAML wildtype with Xbal } \\
\text { and Eco81I and then ligating }\end{array}$ & this thesis \\
\hline CAML_SSSSS & $\begin{array}{l}\text { Expression of CAML in S. Cerevisiae } \\
\text { the mutations were introduced by cutting } \\
\text { CAML_SCCCC and CAML_CSSSS with Xbal } \\
\text { and SacII(2X) and then ligating }\end{array}$ & this thesis \\
\hline
\end{tabular}

\subsubsection{Primers}

The primers were named after the gene they amplify and the position of the cysteine that was changed to serine. The company Sigma-Aldrich manufactured them. For $=$ forward primer, Rev $=$ reverse primer

Table 5: Primers

\begin{tabular}{|l|l|l|}
\hline$\#$ & Name & Sequence $\left(5^{\prime}-3^{\prime}\right)$ \\
\hline 1 & WRB-C21S-For & CAG CTT CGT GTT TGG AAG CAA TGT TCT TAG G \\
\hline
\end{tabular}




\begin{tabular}{|l|l|l|}
\hline 2 & WRB-C21-S-Rev & CCT AAG AAC ATT GCT TCC AAA CAC GAA GCT G \\
\hline 3 & WRB-C157-162S-For & GTT GGA ATT ACC TCT TGG ATT TTA GTC TCT AAC AAA GTT G \\
\hline 4 & WRB-C157-162S-Rev & CAA CTT TGT TAG AGA CTA AAA TCC AAG AGG TAA TTC CAA C \\
\hline 5 & CAML-C121S-For & CAT TAA AGC ACC AGA GAG CAG TAG TAA GGA TGG AGC \\
\hline 7 & $\begin{array}{l}\text { CAML-C121S-Rev } \\
\text { For }\end{array}$ & $\begin{array}{l}\text { GCT CCA TCC TTA CTA CTG CTC TCT GGT GCT TTA ATG } \\
\text { CCT TTG TTA GCA AAT ATT TG }\end{array}$ \\
\hline 8 & $\begin{array}{l}\text { CAML-C194-206S- } \\
\text { Rev }\end{array}$ & $\begin{array}{l}\text { CAA ATA TTT GCT AAC AAA GGC TCT GAC GCC AAG AGC GAG } \\
\text { CAG AGC GCT CCC CAC CAA TC }\end{array}$ \\
\hline 9 & CAML-C273-282S- & $\begin{array}{l}\text { CAC GGA CCT CAG CGT CTA CTT CTT CAC CTT CAT TTT CTC TCA } \\
\text { TGA ACT GC }\end{array}$ \\
\hline
\end{tabular}

The GC-fraction of the primers was 35-52.5 \%.

\subsection{Methods}

\subsubsection{Molecular Biology Methods}

\subsubsection{Cloning}

Variants of the WRB and CAML genes were generated by mutating cysteines to serines. To introduce those changes in the gene mutagenesis PCRs were performed.

\subsection{Quick-Change Mutagenesis Polymerase chain reaction (PCR)}

The quick-change mutagenesis PCR operates with primers that have almost complementary sequences to the original gene sections. However, single base pairs are changed while the section around the mutation site is complementary so it can anneal with the gene of interest. Like a standard PCR, the mutagenesis PCR also is an in vitro 
technique to exponentially amplify specific fragments of DNA. Because complementary forward and reverse primers were used for those experiments, a special protocol was applied to avoid that the primers might bind to each other. The SPRINP (Two Single Primer Reactions in Parallel) method (Edelheit et al. 2009) was used, performing a single PCR reaction for each primer creating single strands of the DNA and afterwards both single strands were annealed in an additional step.

In the first step of the PCR, the hydrogen bonds are disrupted due to heating up to $98^{\circ} \mathrm{C}$. It is called denaturation and results in single stranded DNA molecules. During the Annealing step, having temperatures around $50{ }^{\circ} \mathrm{C}$, the primers anneal to their complementary DNA fragment. Lowering the annealing temperature promotes annealing of primers containing mismatches to target sequences on the template DNA.

The elongation step is performed at $72{ }^{\circ} \mathrm{C}$, which is the optimum temperature for the Taq polymerase that was used. The polymerase binds to the primer-DNA hybrid and performs the extension by adding complementary dNTPs in $5^{\prime}$ to $3^{\prime}$ direction to the primer. This is a condensation reaction where the $5^{\prime}$-phosphate group of the dNTP is connected with the 3'-hydroxyl group.

Those three steps are repeated for 30 times to exponentially increase the amount of new strands containing the mutation. In the end, there is a final elongation step to make sure that uncompleted single stranded DNA molecules are extended. After this, the temperature holds at $4{ }^{\circ} \mathrm{C}$ to conserve the products until they are taken out of the PCR machine.

\section{Materials and Equipment}

Phusion High Fidelity DNA Polymerase 2U/ $\mu$ l (New England Biolabs)

Phusion High Fidelity Buffer 5x (New England Biolabs)

dNTP Mix (10 mM dATP, 10 mM dGTP, 10 mM dCTP, 10 mM dTTP)

Primers (ordered from GATC Biotech) diluted to $100 \mu \mathrm{M}$

PCR tubes

Thermocycler 
Dimethyl sulfoxide (DMSO)

PCR reaction mixture:

Table 6: PCR reaction mixture

\begin{tabular}{|l|l|}
\hline Template DNA & $0.5 \mu \mathrm{l}(500 \mathrm{ng})$ \\
\hline 5x Phusion HF buffer & $5 \mu \mathrm{l}$ \\
\hline dNTP mix & $2 \mu \mathrm{l}$ \\
\hline DMSO & $1.25 \mu \mathrm{l}$ \\
\hline $\mathrm{H}_{2} \mathrm{O}$ & $11.55 \mu \mathrm{l}$ \\
\hline Phusion HF polymerase & $0.5 \mu \mathrm{l}$ \\
\hline Forward primer/reverse primer & $4.2 \mu \mathrm{l}$ \\
\hline Total & $25 \mu \mathrm{l}$ \\
\hline
\end{tabular}

For each PCR two reactions were performed: one containing the forward and one containing the reverse primer.

Amplification program:

Steps 2-4 were repeated for 30 cycles.

Table 7: PCR steps

\begin{tabular}{|c|c|c|}
\hline Step & Temperature $\left[{ }^{\circ} \mathrm{C}\right]$ & Time \\
\hline 1 & 98 & $2 \min$ \\
\hline 2 & 98 & $30 \mathrm{sec}$ \\
\hline 3 & $45-55$ & $30 \mathrm{sec}$ \\
\hline 4 & 72 & $3 \mathrm{~min} 30 \mathrm{sec}$ \\
\hline 5 & 72 & $5 \mathrm{~min}$ \\
\hline 6 & 4 & $\infty$ \\
\hline
\end{tabular}


After the amplification, both reaction mixes were merged with each other to start the annealing of the products according to the program below:

Table 8: Annealing steps

\begin{tabular}{|l|l|l|}
\hline Step & Temperature $\left.{ }^{\circ} \mathrm{C}\right]$ & Time \\
\hline 1 & 95 & $5 \mathrm{~min}$ \\
\hline 2 & 90 & $1 \mathrm{~min}$ \\
\hline 3 & 80 & $1 \mathrm{~min}$ \\
\hline 4 & 70 & $30 \mathrm{sec}$ \\
\hline 5 & 60 & $30 \mathrm{sec}$ \\
\hline 6 & 50 & $30 \mathrm{sec}$ \\
\hline 7 & 40 & $30 \mathrm{sec}$ \\
\hline 8 & 37 & $\infty$ \\
\hline
\end{tabular}

The products were digested by Dpnl to remove non-mutated plasmids before the transformation. Dpnl is a restriction enzyme able to recognize and cut methylated DNA but not non-methylated. Cloned plasmids only consist of non-methylated DNA.

Finally, the transformation to E. coli was performed. After the transformation worked, the DNA was purified from the cells.

Materials and Equipment:

Restriction enzymes (NEB)

$10 \times$ Restriction enzyme buffer (NEB)

$100 \times$ BSA (NEB)

T4 DNA Ligase (NEB) 
T4 DNA Ligase Buffer (NEB)

PCR product purification kit

Agarose 0.05 - 50 kbp (peqlab)

Plasmid DNA purification kit (Macherey-Nagel)

Nucleobond midi prep kit (Macherey-Nagel)

$6 \times$ Gel loading dye (NEB)

E. coli DH5- $\alpha$ cells

LB ampicillin plates

UV transluminator (GelStick)

\section{Restriction digestion:}

To perform the digestions the appropriate buffer and the temperature recommended by the manufacturer (NEB) were used. The digestions were performed for one hour. Both insert and vector, were digested with the same enzymes.

Table 9: Restriction digestion

\begin{tabular}{|l|l|}
\hline DNA & Amount \\
\hline $\begin{array}{l}\text { Restriction } \\
\text { enzyme }\end{array}$ & $1 \mu \mathrm{g}$ \\
\hline Buffer 10X & $4 \mu \mathrm{l}$ \\
\hline $\mathrm{dH}_{2} \mathrm{O}$ & \\
\hline Total & $40 \mu \mathrm{l}$ \\
\hline
\end{tabular}

After digesting and leaving it run on a gel, the correct bands were then cut out and purified from the gel according to the Plasmid DNA purification kit (Macherey-Nagel) protocol. 
The ligations were performed with an insert/vector-ratio of 9:1, which was calculated based on the length of both fragments. A negative control sparing the insert was always performed as well. The ligations were performed for either one hour at $37{ }^{\circ} \mathrm{C}$ or overnight at $16^{\circ} \mathrm{C}$.

Table 10: Ligation

\begin{tabular}{|l|l|}
\hline & Volume \\
\hline Vector & $100 \mathrm{ng}$ \\
\hline Insert & Volume according to the insert/vector-ratio calculation \\
\hline T4 Buffer $10 \mathrm{X}$ & $2 \mu \mathrm{l}$ \\
\hline T4 Ligase & $1 \mu \mathrm{l}$ \\
\hline $\mathrm{dH}_{2} \mathrm{O}$ & \\
\hline Total & $20 \mu \mathrm{l}$ \\
\hline
\end{tabular}

\subsection{Electroporation: Transformation of bacteria cells}

Electroporation is a method to insert plasmid DNA into bacteria cells by making the bacterial cell membrane temporary permeable applying a rapid and intense electric pulse.

At least $30 \mathrm{ng}$ of DNA from the ligation were added to a vial containing $50 \mu \mathrm{l}$ of competent $\mathrm{DH} 5-\alpha$ cells, which were before stored at $-80^{\circ} \mathrm{C}$ in glycerol $10 \%$. The mixture was transferred to a cold cuvette of $0.2 \mathrm{~cm}$ gap and the electroporation was performed at $2.5 \mathrm{kV}$. After this, the cells were grown in $1 \mathrm{ml}$ of S.O.C. medium at $37^{\circ} \mathrm{C}$ and $900 \mathrm{RPM}$ for $1 \mathrm{~h}$. The cells were centrifuged ( $3400 \times \mathrm{g}, 1 \mathrm{~min}$ ), plated on ampicillin plates and incubated at $37^{\circ} \mathrm{C}$ for $16 \mathrm{~h}$.

Those cells that received the plasmid are afterwards selected on LB medium supplemented with ampicillin. The transformed plasmid includes the coding sequence to express $\beta$-lactamase, an enzyme that metabolizes ampicillin. Selected colonies were 
grown at $37^{\circ} \mathrm{C}, 120$ RPM overnight in liquid LB-Amp and plasmid DNA was then isolated via a mini prep kit.

The Nucleo Spin ${ }^{\circledR}$ Plasmid Mini-Kit (Machery-Nagel) was used to obtain the DNA. For isolation of bigger amounts of plasmid DNA, the $E$. coli cells were grown in $200 \mathrm{ml}$ LB medium overnight and purified with the midi prep kit.

\subsection{Agarose gel electrophoresis}

This method is used to separate DNA molecules according to their molecular weight in an agarose gel. For this purpose, the negative charge of the DNA backbone is used. It lets the DNA wander to the anode through the gel. When the DNA is pulled through the gel matrix, it is separated by its length. Small molecules are faster than large ones in the agarose net. By using a marker as reference, it is possible to identify bands as specific DNA fragments.

The concentration of the agarose in the gel determines the resolution properties of the gel matrix and for this reason the running speed of the DNA. For example, a gel with a high percentage would be good for the separation of small molecules.

The non-toxic agent Safeview (molecular formula: $\mathrm{C}_{21} \mathrm{H}_{28} \mathrm{~N}_{4}$ ) is a component of the gel, which lets the DNA bands fluoresce under UV light.

In this thesis were used $1 \%$ agarose gels. They were made of $1.5 \mathrm{~g}$ agarose and $150 \mathrm{ml}$ TAE buffer. The solution was completely dissolved by heating in the microwave for 3 minutes. After short cooling and adding $15 \mu \mathrm{l}$ Safeview the solution was poured into the rack to solidify. A comb formed the pockets for DNA and marker.

The solid gel was placed in the electrophoresis chamber and covered by TAE buffer. DNA buffer $6 \mathrm{X}$ was added to the probes before they were put into the pockets. The gel run was started at constant current of $50 \mathrm{~mA}$ and was increased to $100 \mathrm{~mA}$ after the samples entered the gel. It took about $90 \mathrm{~min}$ and was afterwards analysed in the UV transluminator, pictures were taken using a GelStick apparatus.

If necessary, DNA bands were cut out of the gel under the UV transluminator avoiding too long UV light exposure times. Afterwards they were purified with a High Pure PCR Product Purification Kit (Roche). 


\subsection{Measurement of DNA concentration}

The DNA concentration of the probes was measured using a NanoDrop spectrophotometer (ThermoScientific). Extinction of light was measured and the concentration (c) was calculated by the machine according to the Beer-Lambert law.

$$
E=\varepsilon_{\lambda} * c * d
$$

E: extinction

$\varepsilon:$ Molar absorptivity

$\mathrm{d}$ : thickness of the cuvette

\subsection{DNA sequencing}

The company GATC Biotech AG (Konstanz, HRB 381757) did Sanger sequencing.

\subsubsection{SDS-PAGE and immunoblot}

\section{SDS-PAGE}

SDS-PAGE (sodium dodecyl sulfate polyacrylamide gel electrophoresis) is a method used to separate proteins in a gel according to their molecular weight. Large proteins migrate more slowly in the gel than small proteins do. However, because different proteins have a unique net electric charge, which has an impact on their running behaviour in the electric field, they have to be treated at first. The anionic tenside SDS coats the proteins and gives them a negative charge while the reducing agent DTT (dithiothreitol) disrupts disulphide bonds. Subsequent sample boiling allows denaturation and a predominantly linear conformation of the protein. After these treatments, the protein's running behaviour depends only on its molecular weight.

There are different types of polyacrylamide gels that are used for SDS-PAGE. For experiments with proteins of very diverse molecular weights, it is possible to use gradient gels. These gels have an acrylamide concentration of 3-20 \%, linearly increasing 
in running direction. If proteins with similar molecular weights should be separated, gels with a constant concentration of acrylamide are used. This method with $12 \%$ polyacrylamide gels, which are appropriate for protein weights of 25-100 kDa, was mainly used in this thesis.

In addition to the running gel where the proteins are separated, there is a stacking gel with lower acrylamide concentration ( $5 \%$ for this thesis). This gel concentrates the proteins before entering the running gel, what makes the bands more clean and clear.

\section{Casting of polyacrylamide gels}

The glass wafers of the gel caster were washed with ethanol, assembled in the rack and then the chambers were tested on leak tightness with distilled water. Then the gels were casted with the following composition:

Table 11: Polyacrylamide gels

\begin{tabular}{|l|l|l|}
\hline & stacking gel $5 \%[\mathrm{ml}]^{*}$ & $\begin{array}{l}\text { running/resolving gel } 12 \% \\
{[\mathrm{ml}]^{*}}\end{array}$ \\
\hline $\mathrm{H}_{2} \mathrm{O}$ & 5.5 & 3.3 \\
\hline Acrylamide mix (30 \%) & 1.3 & 4.0 \\
\hline $1.5 \mathrm{M}$ Tris (pH 8.8) & - & 2.5 \\
\hline $1.0 \mathrm{M}$ Tris (pH 6.8) & 1.0 & - \\
\hline SDS (10 \%) & 0.08 & 0.1 \\
\hline $\begin{array}{l}\text { Ammonium persulfate (10 } \\
\text { \%) }\end{array}$ & 0.08 & 0.1 \\
\hline TEMED & 0.008 & 0.004 \\
\hline
\end{tabular}

*volumes for two gels

After casting the resolving gels in the chambers and leaving $2.5 \mathrm{~cm}$ space to the top for the stacking gel, $500 \mu \mathrm{l}$ isopropanol was poured on top of it to get a plain surface. The polymerization of the resolving gel took 45 minutes. The fluid was removed, the chamber was filled to the top with stacking gel and a comb to form the chambers for the protein lysates was plugged in the liquid gel. 
In the first pocket $1 \mu \mathrm{l}$ marker was loaded to see what size detected bands have and in each other pocket was loaded 15-30 $\mu$ l of protein lysate.

The gel run was started at $15 \mathrm{~mA}$ per gel and increased to $30 \mathrm{~mA}$ per gel when the markers reached the resolving gel. As the markers arrived at the lower gel edge, the running was stopped.

\section{$\underline{\mathrm{NaOH} \text {-Lysis of yeast cells }}$}

To extract the proteins from the S. cerevisae cells they were first centrifuged during the exponential growth phase and then resuspended in $100 \mathrm{mM} \mathrm{NaOH}$. After incubation for ten minutes at room temperature, they were pelleted again and resuspended in variable volumes of 1 X SDS-sample-buffer according to cell density. After this, the suspension was heated for five minutes at $95{ }^{\circ} \mathrm{C}$, then pelleted and the supernatant was used as protein-lysate.

\section{$\underline{\text { Immunoblot }}$}

Immunoblot is a method to detect specific proteins based on recognition of an epitope by an antibody. Proteins, previously separated by SDS-PAGE, are transferred to a nitrocellulose membrane what makes them accessible for antibody detection. The setting of the transfer sandwich was done according to manufacturer's manual. Transfer took 80 minutes at $60 \mathrm{~V}$ and $0.5 \mathrm{~A}$.

After the transfer, the membranes were stained with ponceau-S solution for 5 minutes. This confirmed if the proteins were correctly transferred to the membrane. Ponceau-S binds unspecifically to any protein.

In the next step the membrane was blocked in milk, which binds everywhere on the membrane where no protein is present. Following the blocked membrane is incubated with the primary antibody in milk that binds specific to a protein (e.g. WRB or CAML) overnight at $4{ }^{\circ} \mathrm{C}$ and afterwards the membrane was washed with $1 \mathrm{x}$ PBS-T three times for five minutes. Finally, the membrane was incubated with the secondary antibody in milk for one hour at room temperature, then washed again three times in $1 \times$ PBS-T and scanned in the Licor Odyssey. 
Materials and Equipment

Acrylamide $30 \%$

Tetramethyethylenediamine (TEMED)

Ammonium persulfate $10 \%$

SDS $10 \%$

1,5 M Tris-buffer $(\mathrm{pH} 8,8)$

$1 \mathrm{M}$ Tris-buffer $(\mathrm{pH} \mathrm{6,8)}$

Protein ladders

Nitrocellulose membrane

Luminescent image analyser

\subsubsection{Microscopy techniques}

\subsubsection{Fluorescence microscopy}

Live cell images were acquired at room temperature on a Delta Vision RT (Applied Precision) microscope using a 100 x / 0.35-1.5 Uplan Apo objective plus specific band pass filter sets for GFP. The images were taken by a Coolsnap HQ (Photometrics) camera. ImageJ (http://rsbweb.nih.gov/ij/) was used for image processing. Having at least 20 fields per sample Pixel fluorescence intensity was quantified using Knime software (www.knime.org/knime).

Distribution of Sed5 was monitored using Knime software. Each pixel per cell was distributed across bins of fluorescence intensity. To identify and quantify structures of high fluorescence intensity resembling Golgi vesicles and areas of average fluorescence intensity resembling cytosol.

Sed5 is a SNARE tail-anchored protein involved in Golgi-ER trafficking used in several other studies to track the GET pathway (Schuldiner et al. 2008; Voth et al. 2014). 


\subsubsection{Yeast culture methods}

\subsubsection{Yeast strains}

S. cerevisiae strain NMY51 (MATa his3delta200 trp1-901, leu2-3,112 ade2, LYS2::(lexAop) ${ }_{4}$-HIS3 ura3::(lexAop) ${ }_{8}$-lacZ (lexAop) ${ }_{8}$-ADE2 GAL4) for split-ubiquitin yeast two-hybrid was obtained from Dualsystem Biotech. $\Delta$ get1/get2 strain was previously described in Schuldiner et al, 2008.

Cells were grown in Hartwell's Complete $(\mathrm{HC})$ medium. All experiments were performed at mid-log phase.

\subsubsection{Yeast transformation}

DNA was transformed into yeast cells. Initially cells of the yeast strain from the stock were inoculated in $4 \mathrm{ml}$ liquid medium and incubated at $30^{\circ} \mathrm{C}$ overnight. Depending on the growth rate of the strain used, this time may vary. Before further procedure the culture should have an $\mathrm{OD}_{600}$ of $0.5-1.2$ which means that it is in the mid to late logarithmic growth phase.

The cells (5 $\mathrm{ml}$ per transformation) were centrifuged at $1000 \mathrm{~g}$, room temperature for five minutes and then washed in sterile water. The pellet was resuspended with $200 \mu \mathrm{l}$ lithium acetate mix per transformation, $0.5 \mu \mathrm{g}$ DNA and $18 \mu \mathrm{l}$ carrier DNA (10 mg/ml) were added. Carrier DNA was boiled before for $60 \mathrm{sec}$ in the microwave. The mixture was vortexed, $1.2 \mathrm{ml} \mathrm{PEG} \mathrm{mix} \mathrm{were} \mathrm{added} \mathrm{and} \mathrm{vortexed} \mathrm{again.} \mathrm{These} \mathrm{samples} \mathrm{were} \mathrm{then}$ incubated for $40 \mathrm{~min}$ at room temperature and an additional $20 \mathrm{~min}$ at $42{ }^{\circ} \mathrm{C}$. After spinning down again the supernatant was removed, cells were resuspended in $100 \mu \mathrm{l}$ sterile water and streaked out on selective plates. Finally, the cells were grown at $30{ }^{\circ} \mathrm{C}$ for 2-3 days. 


\subsubsection{Split-ubiquitin yeast two-hybrid assay and spotting}

To investigate interaction between two proteins the split-ubiquitin yeast two-hybrid assay designed by the company Dualsystem was used. This assay uses the HIS3 gene activation as a marker for protein interaction and as the cells are selected on plates depleted of histidine, only cells with interacting WRB and CAML are able to produce histidine and grow on histidine-depleted medium. The system is further described in chapter 3.2.

Colonies of the co-transformed yeast strains were inoculated in HC-ura-leu medium and grown overnight before they were diluted to an $\mathrm{OD}_{600}$ of 0.2 . Finally, $1: 5$ serial dilutions were spotted on HC-ura-leu-met or HC-ura-leu-met-his plates. 


\section{Results}

I aimed to investigate the role of cysteine residues of WRB and CAML in the interaction between the two membrane proteins that form the ER receptor of the mammalian GET pathway. I chose the yeast model for my experiments because yeast features a highly conserved GET pathway and it was shown that mammalian proteins WRB and CAML can functionally replace Get1 and Get2, the proteins forming the receptor of the yeast pathway (1.4.1). Moreover, yeast can easily be manipulated genetically and yeast cells grow much faster than mammalian cells.

The approach was to replace the cysteines with serines and therefore to create several mutant genes encoding variants of WRB and CAML. I aimed to analyse these variants with respect to formation of a heterooligomeric receptor, i.e. to assay WRB-CAML protein-protein interaction. Furthermore, I tested whether these cysteine variants are functional in targeting a yeast TA protein and whether they complement known growth defects of a yeast strain lacking Get1 and Get2.

\subsection{Generation of WRB/CAML mutants}

Using a mutagenesis PCR method, I needed primers to introduce the mutations. In total I obtained ten primers (Table 5: Primers), one forward and one reverse primer for each of the transmembrane domains containing cysteines and also for the cysteine in the cytosolic domain of CAML ( Figure 4: WRB and CAML constructs). These primers were initially used for the quick-change mutagenesis PCR. Because I did not manage to generate all constructs with this method, I switched to the SPRINP method (2.2.1.1). The last constructs were obtained by combinations of restriction digestions and ligations. Table 4: Plasmids in the materials and methods chapter gives details on which plasmid was generated by which method. 


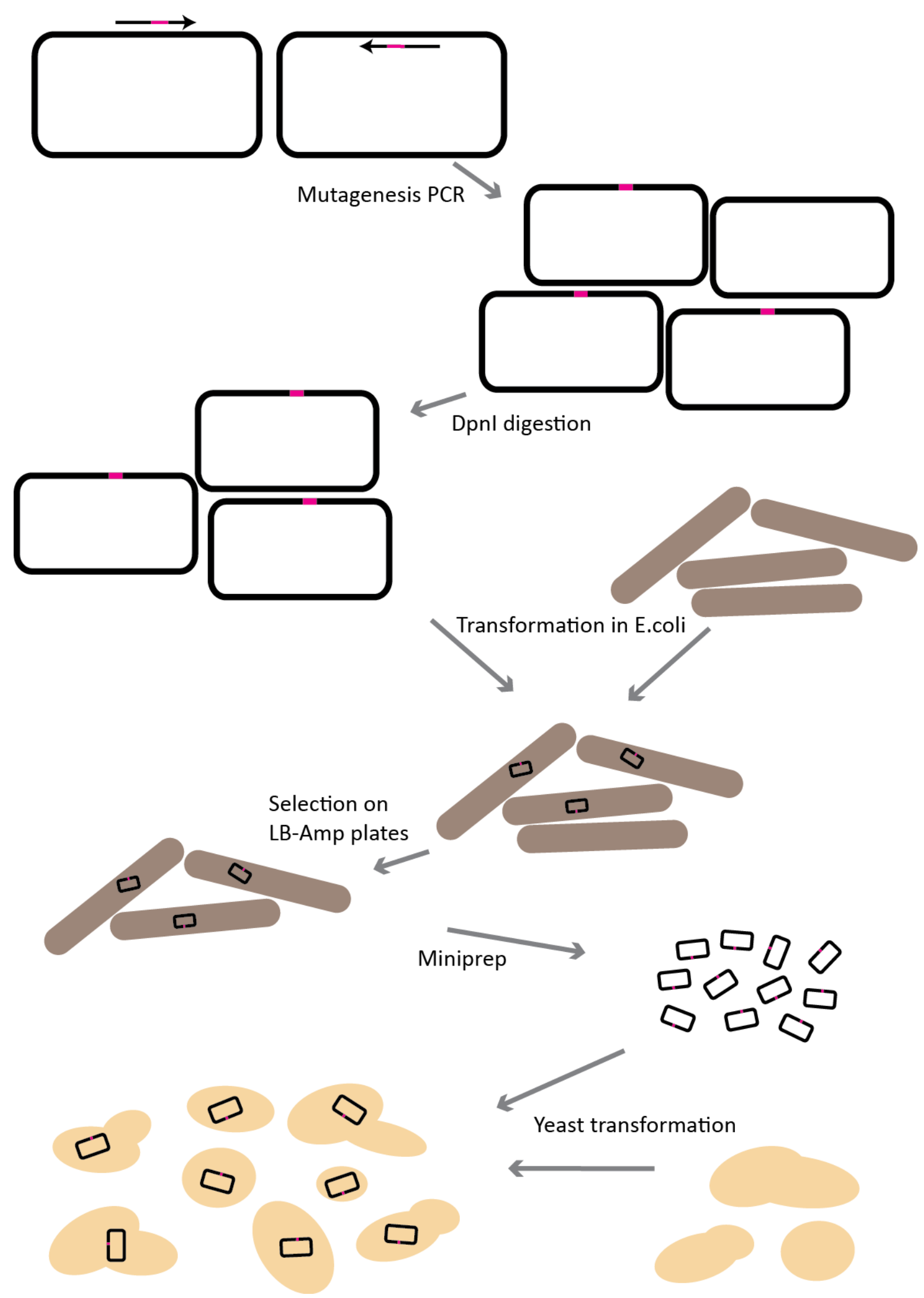

Figure 3: Mutagenesis scheme 
PCR bands with correct base pair length representing expected DNA molecules were first excised from the gel and purified. Secondly, they were digested by Dpnl in order to digest the methylated DNA but not non-methylated DNA. This step allows to select the mutated DNA and prevent transformation of the non-mutated template plasmids.

Transformed bacteria that received the plasmid were selected on LB-Ampicillin plates. The plasmid contains a $\beta$-lactamase gene that provides resistance to the antibiotic. To prepare the amounts of DNA required for the yeast experiments, bacterial cultures were grown to generate material for DNA mini and midi preps. For this purpose, colonies were inoculated in liquid media to grow overnight, then the mini prep was performed and the isolated DNA was sent for Sanger sequencing.

After I generated all of the constructs necessary for my set of experiments the transformation into S. cerevisiae (2.2.3.1) was performed leading to 27 different combinations of WRB and CAML mutants. The number results from the combination of three different WRB proteins (wild type, CSS, SSS) and nine CAML proteins (wild type, empty plasmid not containing any CAML variant, SSSSS, CSSSS, CCCSS, SCCCC, SCCSS, SSSCC, CSSCC). The nomenclature lists the cysteines in the order by which they occur within the linear sequence of the proteins. Wild type WRB contains cysteines at positions 21, 157 and 162. Wild type CAML contains cysteines at positions 121, 194, 206, 273 and 282. 


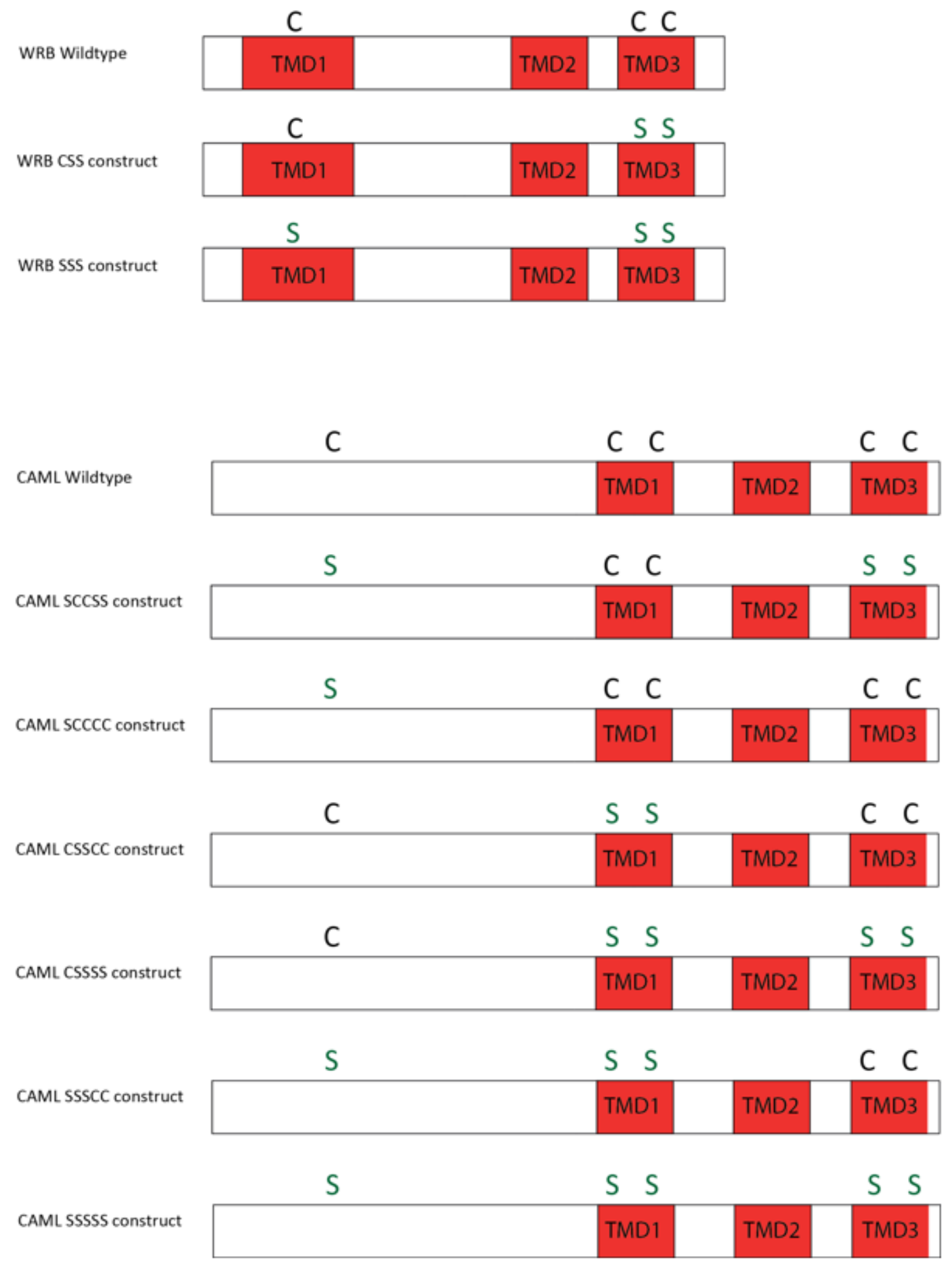

Figure 4: WRB and CAML constructs, C: cysteine position, S: serine position 
To verify the presence of CAML constructs in the co-transformed yeast cells I performed a western blot detecting CAML via an antibody that recognizes an HA epitope fused $\mathrm{N}$ terminally to my CAML constructs (Figure 5).

The blot was performed under reducing conditions. I could detect all CAML mutants and the wildtype above the $35 \mathrm{kDa}$ marker, which confirms presence of the HA-tagged CAML, constructs. Expectedly the mock sample (transformed with an empty vector) did not show any signal. The signal of all constructs appeared in double bands, which was described in other studies before as well for CAML. Samples containing constructs that are mutated at the second and third cysteine position have faster migrating bands in the gel than others, which still express the original cysteines at these positions.

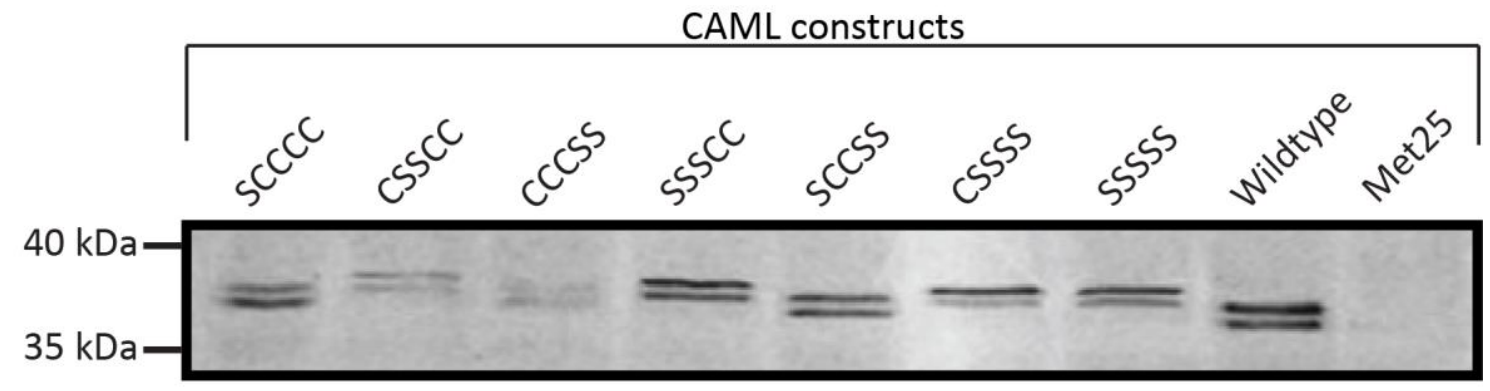

Figure 5: CAML western blot detection; using the co-transformed yeast cell's protein lysate a western blot was performed to confirm the presence of CAML constructs, Met25: Mock, primary antibody: $\alpha-H A \_m o u s e$, secondary antibody: IRDye 680LT Donkey $\alpha$-Mouse IgG $(\mathrm{H}+\mathrm{L})$ 


\subsection{The role of cysteine residues in the formation of the mammalian GET receptor}

To investigate the cysteine dependency of protein interaction between CAML and WRB I have used the split-ubiquitin yeast two-hybrid assay (2.2.3.3).

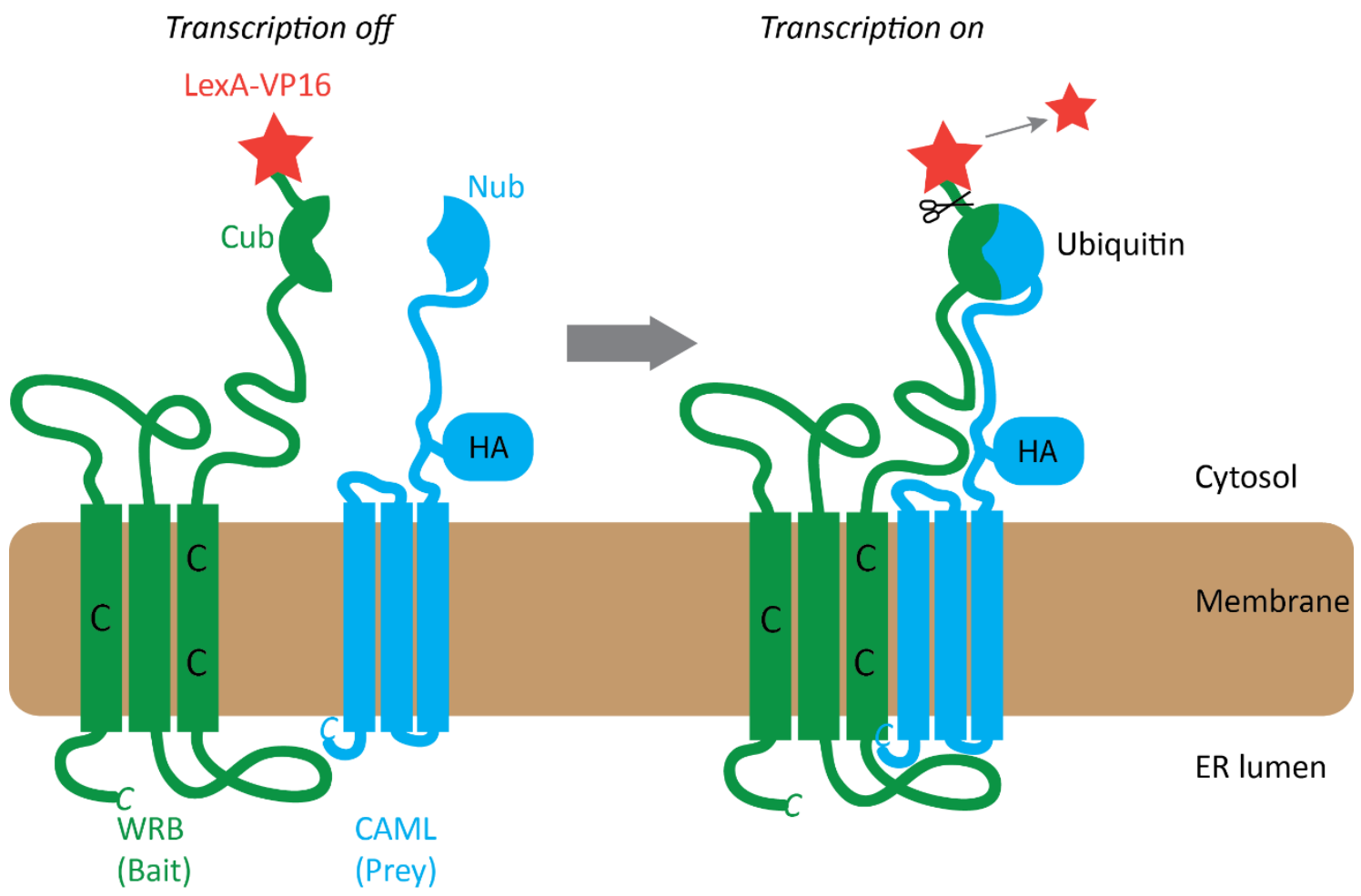

Figure 6: Schematic representation of the split-ubiquitin yeast two-hybrid assay with WRB wild type; HA: HA-epitope, LexA-VP16: LexA-epitope

The C-terminal part of ubiquitin is fused to WRB (Cub) while CAML or its mutants are tagged with the N-terminal part of ubiquitin (Nub). WRB is used as bait protein while CAML works as prey protein. If bait and prey protein interact ubiquitin is recomposed. This activates a protease that releases the LexA-VP16 transcription factor now able to translocate into the nucleus and activate the HIS3 gene. I used this assay to determine whether the cysteines in WRB and CAML are necessary for their interaction with each other and hence for the formation of a heterooligomeric GET receptor. 


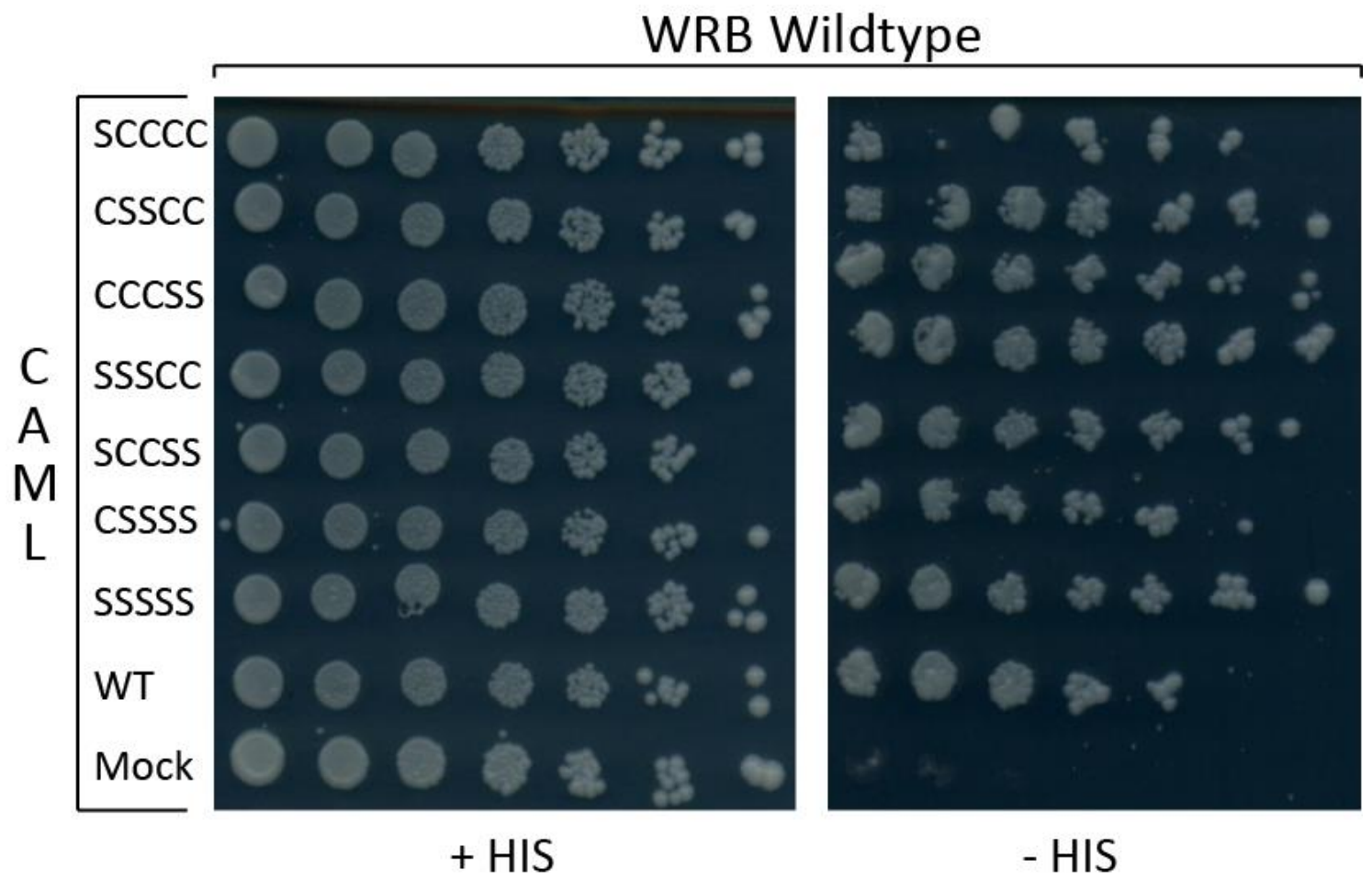

Figure 7: Role of cysteine residues in CAML for its interaction with WRB: Yeast cells (NMY51 strain) were transformed with a combination of WRB and wildtype or mutant CAML for splitubiquitin yeast-two-hybrid analysis. Serial dilutions were spotted on HC-ura-leu-his.

Initially I investigated the role of cysteine residues in CAML for its interaction with WRB. For this purpose, yeast cells were transformed with a combination of WRB and wild type or mutant CAML. The co-transformed yeast cells were spotted in serial dilutions on histidine rich and histidine depleted media. Medium containing histidine serves as a growth control while on histidine depleted plates only cells able to express the HIS3 gene and thus produce histidine survive.

I observed all my co-transformed cells growing on histidine depleted plates, which demonstrates the interaction between WRB, and CAML is not dependent on cysteines in CAML. Reduced growth of cells containing SCCCC and CSSSS was not reproducible in other experiments.

As expected full growth of cells containing all plasmid combinations on histidine rich media was observed. I employed cells lacking a CAML construct (empty p415_MET25 vector) as a negative control for the CAML-WRB interaction. Consistent with the interpretation that growth on histidine-depleted plates reflects an interaction between CAML and WRB, cells without any CAML construct (Met25 empty vector, bottom row) did not survive on histidine-depleted media. 
Then I tested the dependency of the interaction of WRB and CAML from the presence of cysteines in WRB. Performing the split-ubiquitin yeast two-hybrid assay with the WRB CSS mutant, I analysed the role of the second and the third cysteine in WRB.
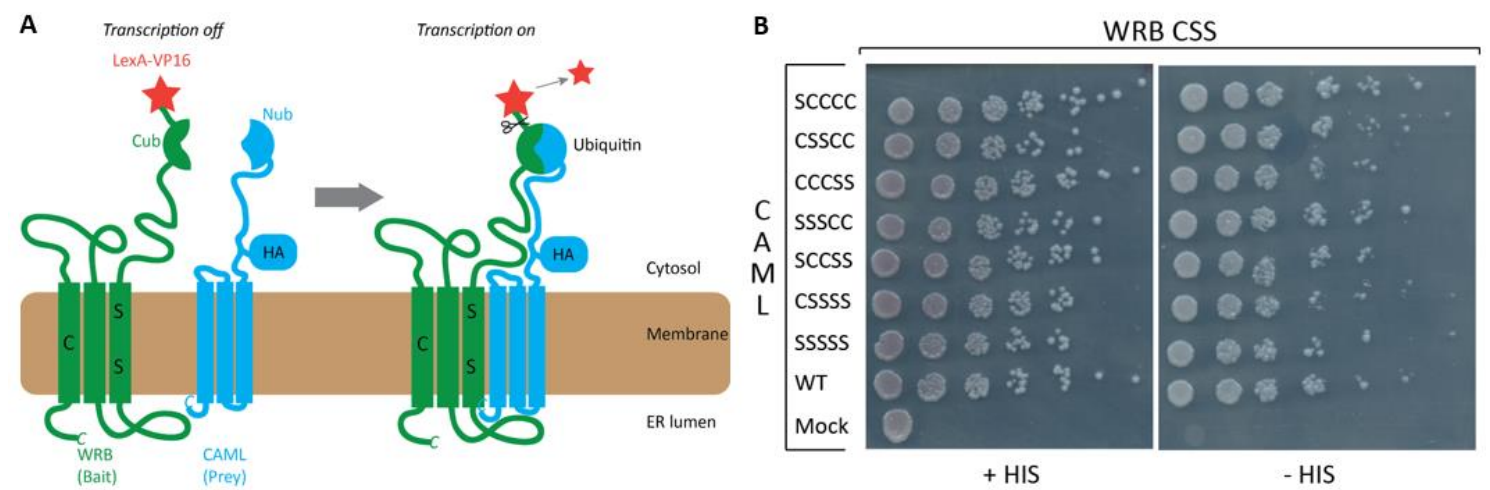

Figure 8: Role of cysteine residues in CAML and cysteines residues 157 and 162 of WRB in the formation of a heterooligomer; A: Split-ubiquitin yeast two-hybrid assay with WRB CSS Construct; B: Serial dilutions spotting on HC-ura-leu and HC-ura-leu-his.

In the spotting assay, I observed again full growth of cells transformed with all the plasmid combinations and therefore I proved that interaction of WRB and CAML is independent from cysteine residues 157 and 162 of WRB. Reduced growth of cells containing CCCSS, SCCSS and SSSSS was not reproducible in other experiments.

To investigate the dependency of the interaction of WRB and CAML from the first cysteine (position 21) in WRB I performed the split-ubiquitin yeast two-hybrid assay and the serial dilution spotting with the WRB SSS mutant co-transformed with CAML wild type or mutants. 

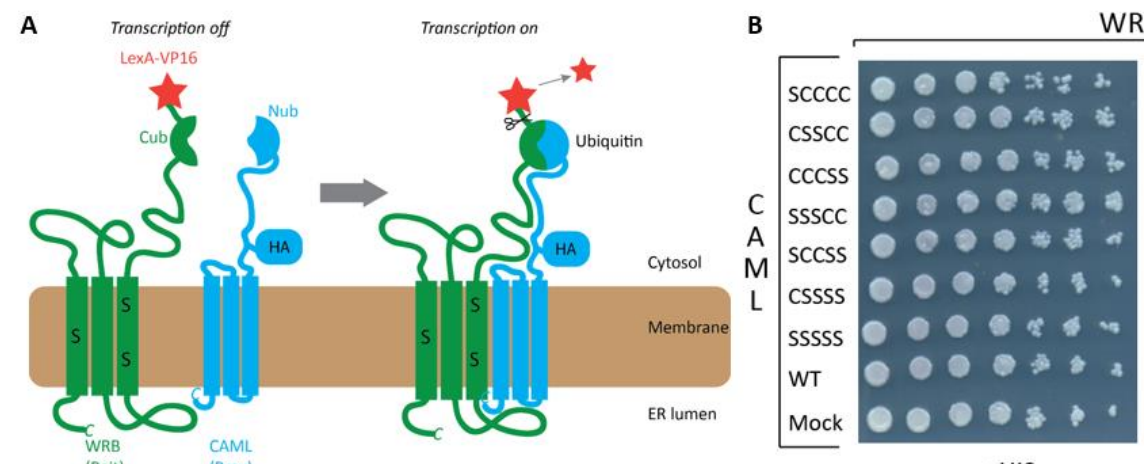

WRB SSS

Figure 9: Cysteine-free variants of WRB and CAML are not impaired in their ability to form a heterooligomer; A: Split-ubiquitin yeast two-hybrid assay with WRB SSS Construct; B: Serial dilutions spotting on HC-ura-leu and HC-ura-leu-his.

All plasmid combinations grew fully demonstrating that cysteine-free variants of WRB and CAML are not impaired in their ability to form a heterooligomer. Reduced growth of cells containing CCCSS, CSSSS and SSSSS was not reproducible in other experiments. Taken together, the data obtained using the split-ubiquitin yeast two-hybrid approach demonstrated that the interaction of WRB and CAML is independent of cysteine residues.

\subsection{TA protein membrane insertion by WRB/CAML cysteine mutants}

To test whether a mutated WRB/CAML receptor complex is still functional and able to insert tail-anchored proteins I transformed $\Delta$ get1/get2 yeast cells with a plasmid containing the coding sequence of GFP-tagged Sed5 and combinations of wildtype or mutant WRB and CAML. GFP-Sed5 is a well-characterized TA protein substrate of the GET pathway. This SNARE is involved in Golgi-ER trafficking and it has been used by several studies to assay the functionality of the GET-pathway. Using fluorescence microscopy, I analysed subcellular GFP-Sed5 localization. 

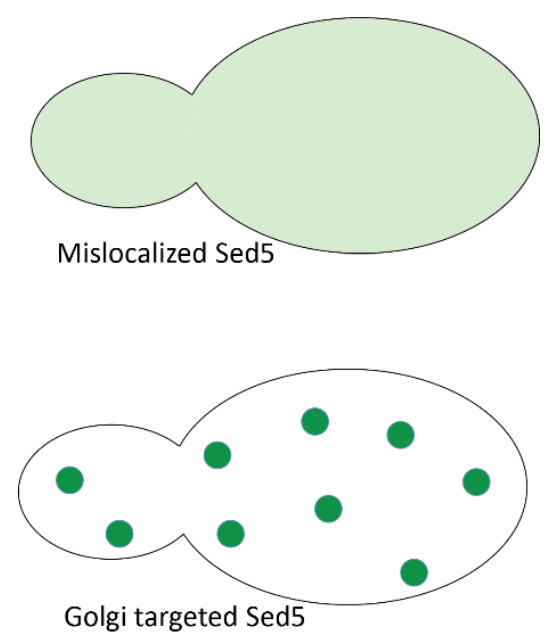

Figure 10: Sed5 localization scheme. Mislocalized GFP-Sed5 accumulates in the cytosol resulting in a diffuse fluorescence all over the cell whereas correctly targeted proteins appear as bright fluorescent clusters resembling Golgi vesicles.

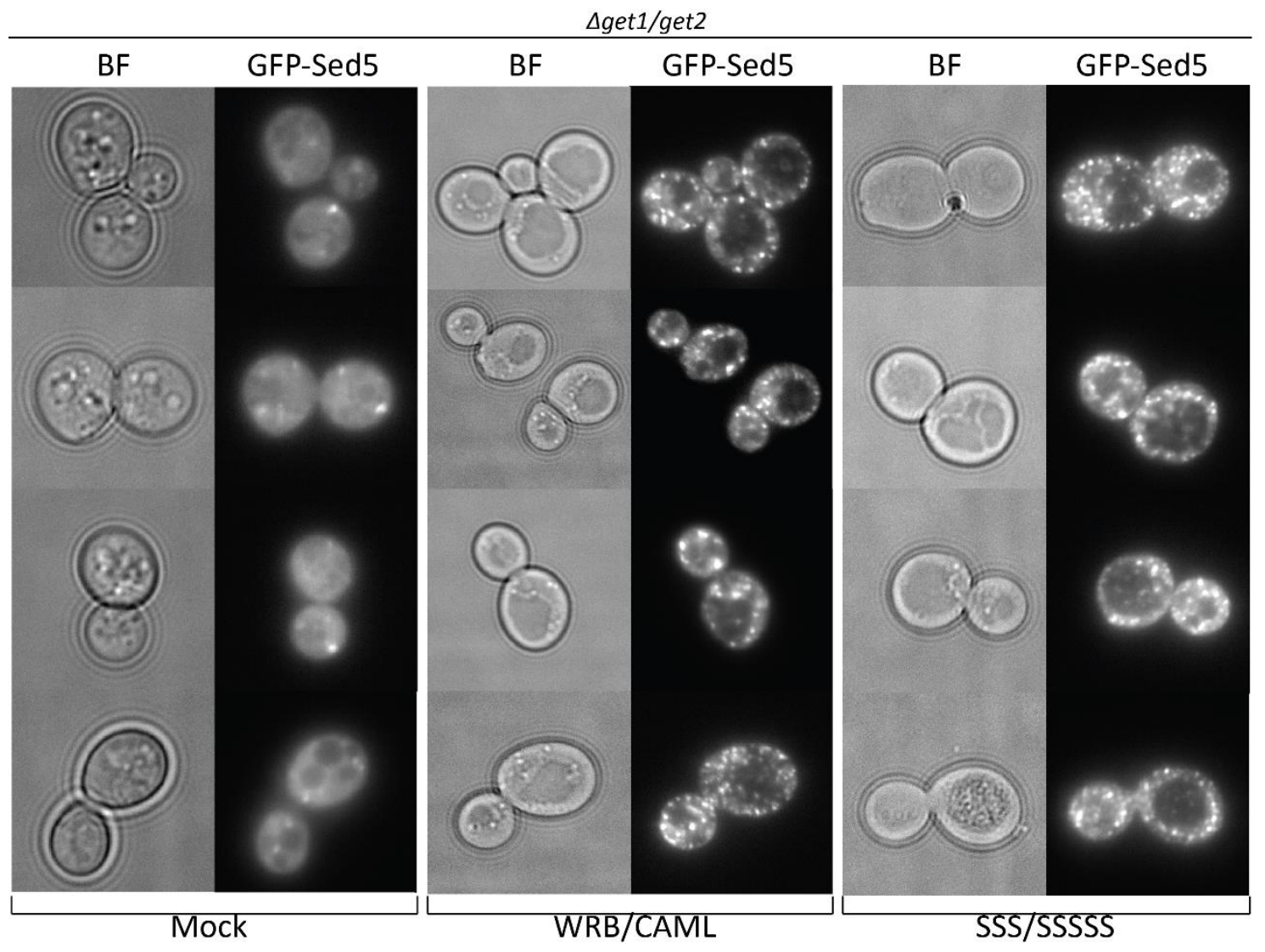

Figure 11: Sed5 targeting; $\Delta$ get1/get2 yeast cells were transformed with a plasmid containing the coding sequence of GFP-tagged Sed5 and combinations of wildtype or mutant WRB and CAML. Subcellular GFP-Sed5 localization was analysed by fluorescence microscopy. 
In yeast cells lacking a functional GET receptor, mislocalized Sed5 appears in a diffuse distribution in the cytosol. In wild type cells or when a functional WRB/CAML receptor is introduced into $\Delta$ get1/get2 yeast cells, Sed5 is correctly targeted and forms bright fluorescent clusters representing Golgi vesicles (Figure 10).

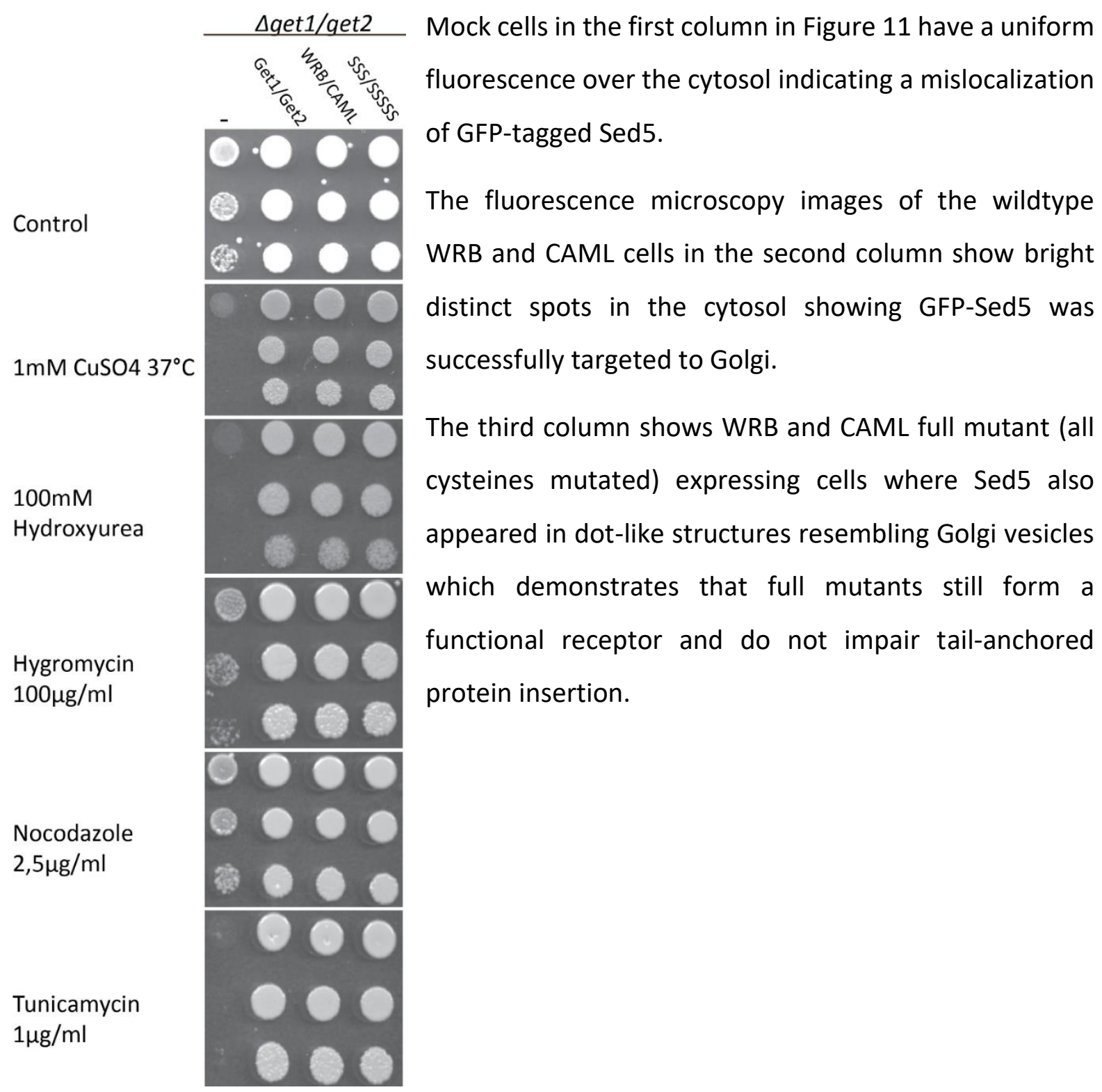

Figure 12: WRB and CAML full mutants rescue the growth phenotypes of $\Delta$ get1/get2 cells; $\Delta$ get1/get2 yeast cells were transformed with wildtype or mutant WRB and CAML or Get1 and Get2 encoding constructs and serial dilutions spotted on different conditions: $\mathrm{HC}$ plates incubated at $30^{\circ} \mathrm{C}$ (control), $37^{\circ} \mathrm{C}+\mathrm{CuSO}_{4}$, hydroxyurea, hygromycin, nocodazole, tunicamycin. 


\subsection{Rescue of growth phenotype of $\Delta$ get $1 / 2$ cells}

Get1/2 deletion causes growth defects under several stress conditions. I wanted to investigate whether my WRB and CAML mutants form a functional receptor that still rescues growth phenotypes under these conditions.

For this purpose, I spotted serial dilutions of cells transformed with Get1/Get2, WRB/CAML wildtypes or WRB/CAML full cysteine mutants on plates resembling several conditions of stress.

To induce oxidative stress I used $1 \mathrm{mM} \mathrm{CuSO}_{4}$ at $37^{\circ} \mathrm{C}$. Hydroxyurea, as a ribonucleotide reductase inhibitor, decreases the production of DNA while hygromycin inhibits translation. Nocodazole impairs microtubules polymerization and therefore effects protein trafficking. Protein unfolding stress is caused by tunicamycin.

The cysteine-free variants containing cells rescued the growth phenotype on all tested conditions (Figure 12).

Cells expressing neither Get1/2 nor any CAML/WRB construct showed impaired growth.

\subsection{WRB/CAML under non-reducing conditions}

Cysteine residues present on WRB and CAML could form inter- or intra-molecular disulphide bonds. This property may affect the functionality of the proteins or their oligomeric state. Therefore, I wanted to find out how my WRB and CAML cysteine variants behave under non-reducing conditions.

For this purpose, I performed two blots loaded with yeast protein lysates of different construct combinations under reducing (with DTT) conditions and two blots under nonreducing (without DTT) conditions. One of each kind was incubated with $\alpha$-LexA to detect WRB and the others were incubated with $\alpha-H A$ in order to detect CAML. The blots are shown in Figure 13 and the green boxes highlight areas of the nitrocellulose membrane that correspond to segments of WRB, CAML or their mutants.

$A$ and $B$ show $\alpha$-LexA detected reducing and non-reducing blots while $C$ and $D$ are corresponding Ponceau-S stained membrane areas. The migration behaviour of WRB 
under non-reducing conditions does not change compared to its migration behaviour under reducing conditions. I could detect unspecific bands at $80 \mathrm{kDa}$ under both reducing and non-reducing conditions that might have occured due to cross-reactions of the antibody with other proteins.

Regarding the running behaviour of CAML (detected via $\alpha-\mathrm{HA}$ in E and F) I come to the same conclusion. It did not change from reducing to non-reducing conditions. What stands out observing these blots is a different running speed between different construct combinations under both reducing and non-reducing conditions. Bands of CAML full cysteine mutant containing protein lysates show slower migration than the CAML wildtype's lysates do.

In spite of loading equal amounts of protein into the gel chambers of reducing and nonreducing gels, remarkably less protein went into the non-reducing gels.

This observation suggests that under non-reducing conditions WRB and CAML (as well as other proteins) may form high molecular weight oligomers that cannot be resolved in the gel system I used. 

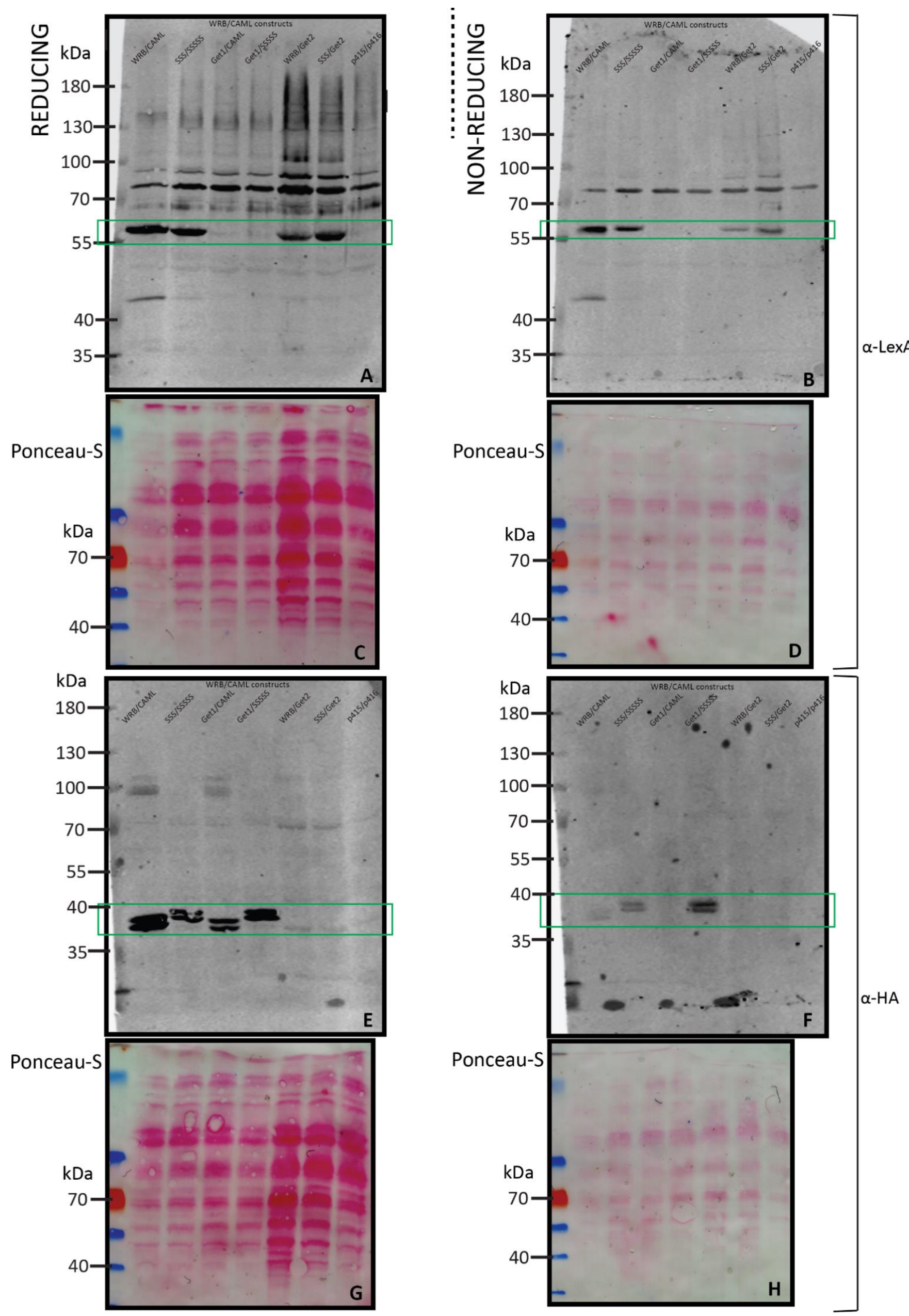
Figure 13: Yeast protein lysate blots under reducing/nonreducing conditions; Detection of CAML or WRB was performed via $\alpha$-HA or $\alpha$-LexA. Ponceau-S-stainings represent corresponding gel areas to the blots above 


\section{Discussion}

\subsection{A cysteine-free variant of the mammalian GET receptor is fully functional in yeast}

The study presented here was undertaken to investigate the function of cysteines introduced during evolution from yeast proteins Get1 and Get2 to the functionally equivalent mammalian proteins WRB and CAML. For this purpose, I generated mutants of WRB and CAML devoid of cysteines that were used in a split-ubiquitin yeast twohybrid assay to test their interaction. I could show the cysteine independency of the interaction between WRB and CAML. Performing a tail-anchored protein targeting assay and analysing subcellular Sed5 distribution by microscopy, I demonstrated that tailanchored protein insertion and targeting are not affected when they are mediated by a cysteine-free receptor formed by WRB and CAML full mutants.

I proved the rescue of growth phenotypes of $\Delta$ get1/get2 mutant strains under several stress conditions by expressing cysteine-free variants of WRB and CAML in yeast cells.

Altogether cysteines and disulphide bonds in WRB and CAML are neither essential for the biogenesis of the receptor nor for recruitment of Get3 to the ER and insertion of tailanchored proteins.

These results are in line with the absence of cysteines in the yeast GET receptor and leave room for a potential and uncharacterized new function of cysteines in the mammalian system.

\subsection{Absence of cysteines changes the running behaviour of CAML}

For detecting CAML I performed western blots with an $\alpha-\mathrm{HA}$ antibody. When CAML was detected, it appeared not only as one but as two bands on the nitrocellulose membrane (Figure 5, Figure 13). This running behaviour of CAML was observed in earlier studies (Vilardi et al. 2014) and may be caused by post-translational modifications when a fraction of CAML proteins is e.g. phosphorylated or glycosylated while another fraction is not. This could result in two different protein sizes detected on the membrane. 
To further investigate this assumption, protein lysates could be treated with enzymes like phosphatases and endoglycosidases that remove modification groups.

Another observation I made performing western blots detecting CAML was a difference in running behaviour depending on the presence of cysteines at positions 194 and 206. If these cysteines are present in CAML it shows a slightly faster migration speed compared to constructs with these cysteines mutated (Figure 5, Figure 13).

Because cysteines are capable of forming intra- and intermolecular disulphide bonds this observation suggests that redox state of a CAML variant may change if cysteines were absent. Hypothesizing that cysteines 194 and 206 in CAML form an intramolecular disulphide bond, this could result in changing of protein structure and therefore running behaviour in the gel.

\subsection{WRB and CAML oligomeric state under non-reducing conditions}

When I investigated WRB's and CAML's behaviour under non-reducing conditions (paragraph 3.5) I noticed that despite loading equal amounts of protein to both reducing and non-reducing gels far less protein was detectable on nitrocellulose membranes under non-reducing conditions.

Because disulphide bonds are maintained under non-reducing conditions a possible explanation is the formation of higher molecular complexes, which accumulate and do not resolve or do not even manage to enter my gel system. I could not observe any WRB or CAML containing complexes at high molecular weight in my resolving gels. Possibly, because they do not form any disulphide bonds or because such postulated high molecular weight complexes do not enter the resolving gel.

A gel system resolving higher molecular weight proteins to study this behaviour could be a gradient gel. The feature of this system is an increasing polyacrylamide concentration e.g. 3-20\% allowing to separate proteins with higher resolution along a much wider range of molecular mass. 


\subsection{Do WRB and CAML play a role in cellular redox balance?}

Fluorescence microscopy experiments (paragraph 3.3) showed the independency of tailanchored protein targeting and insertion from the presence of cysteines in WRB and CAML. If those cysteines are not essential for WRB's and CAML's role in the GET pathway for what reason did evolution introduce them from yeast to mammalian cells? An answer to this question may be that WRB and CAML fulfil further functions in mammalian cells, which are not studied yet.

A recent study about Get3, the protein targeting factor mediating targeting of tailanchored proteins to Get1 and Get2 in the GET pathway in yeast (1.4.1), explored a so far unknown role of Get3 (Voth et al. 2014). Under oxidative stress conditions, Get3 functions as an ATP-independent chaperone and therefore protects eukaryotic cells against protein damage induced by oxidative stress. Upon oxidation, Get3 undergoes an extensive conformational change including cysteine oxidation and release of the zinc ion. This process is fully reversible and helps the cell to survive when ATP level drops down under oxidative stress conditions leading to impaired function of ATP-dependent chaperone systems such as Hsp70 and Hsp90.

Hypothesizing that TRC40, the Get3 homologue in mammalian cells, may also fulfil a chaperone function, WRB and CAML, receptor proteins in the mammalian GET pathway, could potentially be involved in this process. As cysteine oxidation is required for Get3's conformational change, differences in cysteine oxidation state may affect WRB's and CAML's structure and function as well as Get3/TRC40 chaperone activity.

Deletion of Get1 and Get2 does not allow growth of yeast cells under oxidative stress conditions, suggesting that Get3 is not sufficient to cope with oxidative stress and that the GET receptor may have a direct influence on the redox regulated chaperone function of Get3.

A similar function for the mammalian WRB/CAML receptor complex could be postulated. The question is how the redox state of WRB and CAML would affect the hypothetical TRC40 chaperone function. 


\subsection{Intact cellular chaperone function is a protective factor for health}

Protein maintenance is crucial for eukaryotic cell homeostasis. The term proteostasis was recently introduced and includes accurate regulation of protein synthesis, folding, trafficking, aggregation, disaggregation and degradation (Balch et al. 2008). The correct balance of these factors is important for maintenance of the cell proteome and consequently for the health of the organism.

Disruption of proteostasis is progressive with age and may lead to several metabolic, cardiovascular, oncological and neurodegenerative diseases such as loss-of-function disorders like cystic fibrosis and gain-of-function disorders like Alzheimer's and Parkinson's disease (Balch et al. 2008). Pharmaceutical rebalancing of impaired proteostasis has big potential to improve prevention and prognosis of highly prevalent diseases.

Chaperone systems contribute to proteostasis and can be either downregulated preventing cancer and virus resistances or upregulated to delay onset of age-related diseases (Erickson et al. 2006; Massey et al. 2006; Dai et al. 2007; Geller et al. 2007).

Cellular proteostasis adaption occurs continuously and is controlled by stress sensors and inducible pathways that change capacity of protein folding as well as trafficking. These sensor and pathway functions are impaired with age, which in some extent is reason why many diseases are age-onset (Derham and Harding 1997; Erickson et al. 2006) .

Certain disorders like cystic fibrosis and lysosomal storage diseases require higher chaperone capacity, which can be achieved with pharmaceuticals such as proteostasis regulators directed against co-chaperone Aha-1 (Qu et al. 1997; Mu et al. 2008; Wang et al. 2011). Even in Huntington's disease increased chaperone activity ameliorates polyQ proteotoxicity (Morley et al. 2002).

As cysteines in WRB and CAML are not essential for their role in the GET pathway and Get1 and Get2 deletion impairs growth of yeast cells under oxidative stress conditions, WRB and CAML may be necessary for the chaperone function of the mammalian GET pathway. The cysteine residues present in the mammalian receptor and their redox status could be relevant for this proteostasis mechanism. 
Obviously, chaperone activity plays a key role in pathogenesis mechanisms. Therefore, it could be revealing to further study cysteine mutants of WRB and CAML in mammalian cells.

While other protein folding machineries like the Aha-1 co-chaperone are already part of current pharmaceutical research, a better understanding of cellular chaperone systems could identify further chances for medical treatment and if, also the mammalian GET pathway can be a potential pharmacological target in the future. 


\section{Abstract}

Tail-anchored proteins integrate into lipid bilayers via a single transmembrane segment at their extreme C-terminus. The membrane insertion step is mediated by a heterodimeric receptor complex formed by WRB and CAML in higher eukaryotes and Get1 and Get2 in yeast. The transmembrane domains of the receptor complex form an integration site at the endoplasmic reticulum membrane and interact transiently with the transmembrane domain of an integrating TA protein prior to its membrane embedding. Cysteine residues are absent in yeast Get1 and Get2 whereas the mammalian homologues WRB and CAML contain three and five cysteines respectively. I aimed to investigate the role of the cysteine residues of WRB and CAML and test whether they are essential for TA protein targeting. Mutants of WRB and CAML in which the cysteine residues were mutated to serine were generated and I used a yeast-based complementation assay in which cells depleted of Get1 and Get2 were transformed with plasmids encoding either wild type or mutant WRB and CAML. Mutants were still able to create a receptor complex as assayed by yeast two-hybrid and did not impair the targeting of a substrate TA protein. Moreover, mutants rescued growth phenotypes of GET mutants confirming the formation of a functionally active receptor. In line with the absence of cysteines in the yeast GET receptor, cysteines in WRB and CAML seem to be not essential for TA protein targeting and may be required for potential still unknown regulation of TA protein targeting such as receptor stoichiometry, substrate quality control and chaperone function. 


\section{References}

Alberts B: Molecular Biology of the Cell. 6th Edition; Taylor \& Francis, London 2014

Balch WE, Morimoto RI, Dillin A, Kelly JW (2008): Adapting proteostasis for disease intervention. Science $\underline{319}, 916-9$

Bram R, Crabtree G (1994): Calcium signalling in T cells stimulated by a cyclophilin Bbinding protein. Nature $\underline{371}, 355-8$

Braunwald E (2008): Biomarkers in heart failure. N Engl J Med $\underline{358}$, 2148-59

Bryda E, Johnson N, Ohlemiller K, Besch-Williford C, Moore E, Bram R (2012):

Conditional deletion of calcium-modulating cyclophilin ligand causes deafness in mice. Mammalian Genome 23, 270-76

Cichoż-Lach H, Michalak A (2014): Oxidative stress as a crucial factor in liver diseases. World J Gastroenterol 20, 8082-91

D'Autréaux B, Toledano MB (2007): ROS as signalling molecules: mechanisms that generate specificity in ROS homeostasis. Nat Rev Mol Cell Biol 8, 813-24

Dai C, Whitesell L, Rogers AB, Lindquist S (2007): Heat shock factor 1 is a powerful multifaceted modifier of carcinogenesis. Cell $\underline{130}, 1005-18$

Denic V (2012): A portrait of the GET pathway as a surprisingly complicated young man. Trends Biochem Sci 37, 411-7

Derham BK, Harding JJ (1997): Effect of aging on the chaperone-like function of human alpha-crystallin assessed by three methods. Biochem J $\underline{328(\mathrm{Pt} \mathrm{3})}, 763-8$

Dröse S, Brandt U (2012): Molecular mechanisms of superoxide production by the mitochondrial respiratory chain. Adv Exp Med Biol 748, 145-69

Edelheit O, Hanukoglu A, Hanukoglu I (2009): Simple and efficient site-directed mutagenesis using two single-primer reactions in parallel to generate mutants for protein structure-function studies. BMC Biotechnol $\underline{9}, 61$

Erickson RR, Dunning LM, Holtzman JL (2006): The effect of aging on the chaperone concentrations in the hepatic, endoplasmic reticulum of male rats: the possible role of protein misfolding due to the loss of chaperones in the decline in physiological function seen with age. J Gerontol A Biol Sci Med Sci 61, 435-43

Geller R, Vignuzzi M, Andino R, Frydman J (2007): Evolutionary constraints on chaperone-mediated folding provide an antiviral approach refractory to development of drug resistance. Genes Dev 21, 195-205 
Gu X, Sun J, Li S, Wu X, Li L (2013): Oxidative stress induces DNA demethylation and histone acetylation in SH-SY5Y cells: potential epigenetic mechanisms in gene transcription in $A \beta$ production. Neurobiol Aging 34, 1069-79

Hamilton A, Holscher C (2012): The effect of ageing on neurogenesis and oxidative stress in the APPswe/PS1deltaE9 mouse model of Alzheimer's disease. Brain Res $\underline{1449}$, 83-93

Harrison DG (1997): Endothelial function and oxidant stress. Clin Cardiol 20, II-11-7

Imlay JA (2013): The molecular mechanisms and physiological consequences of oxidative stress: lessons from a model bacterium. Nat Rev Microbiol 11, 443-54

Jakob U, Muse W, Eser M, Bardwell JC (1999): Chaperone activity with a redox switch. Cell $\underline{96}, 341-52$

Kalbfleisch T, Cambon A, Wattenberg BW (2007): A bioinformatics approach to identifying tail-anchored proteins in the human genome. Traffic $\underline{8}, 1687-94$

King H, Aubert RE, Herman WH (1998): Global burden of diabetes, 1995-2025: prevalence, numerical estimates, and projections. Diabetes Care 21, 1414-31

Kohl C, Tessarz P, von der Malsburg K, Zahn R (2011): Cooperative and independent activities of Sgt2 and Get5 in the targeting of tail-anchored proteins. Biol Chem $\underline{7}, 601-$ 8

Leichert LI, Gehrke F, Gudiseva HV, Blackwell T, Ilbert M, Walker AK, Strahler JR, Andrews PC, Jakob U (2008): Quantifying changes in the thiol redox proteome upon oxidative stress in vivo. Proc Natl Acad Sci USA 105, 8197-202

Lodish H: Molecular Cell Biology. 6th Edition, W. H. Freeman, New York 2012

Ma K, Nunemaker CS, Wu R, Chakrabarti SK, Taylor-Fishwick DA, Nadler JL (2010): 12Lipoxygenase Products Reduce Insulin Secretion and Beta-Cell Viability in Human Islets. J Clin Endocrinol Metab 95, 887-93

Mariappan M, Mateja A, Dobosz M, Bove E, Hegde RS (2011): The mechanism of membrane-associated steps in tail-anchored protein insertion. Nature $\underline{477}, 61-6$

Masip L, Veeravalli K, Georgiou G (2006): The many faces of glutathione in bacteria. Antioxid Redox Signal $\underline{8}$, 753-62

Massey AC, Kiffin R, Cuervo AM (2006): Autophagic defects in aging: looking for an „emergency exit“? Cell Cycle $\underline{5}, 1292-6$

Morley JF, Brignull HR, Weyers JJ, Morimoto RI (2002): The threshold for polyglutamine-expansion protein aggregation and cellular toxicity is dynamic and influenced by aging in Caenorhabditis elegans. Proc Natl Acad Sci USA $\underline{99}, 10417-22$ 
Mu T-WW, Fowler DM, Kelly JW (2008): Partial restoration of mutant enzyme homeostasis in three distinct lysosomal storage disease cell lines by altering calcium homeostasis. PLoS Biol $\underline{6(2)}$, e26

Nunomura A, Perry G, Aliev G, Hirai K, Takeda A, Balraj EK, Jones PK, Ghanbari H, Wataya T, Shimohama S (2001): Oxidative damage is the earliest event in Alzheimer disease. J Neuropath Exp Neurol $\underline{60}$, 759-67

Qu BH, Strickland EH, Thomas PJ (1997): Localization and suppression of a kinetic defect in cystic fibrosis transmembrane conductance regulator folding. Journal Biol Chem 272, 15739-44

Rabu C, Schmid V, Schwappach B, High S (2009): Biogenesis of tail-anchored proteins: the beginning for the end? J Cell Sci 122, 3605-12

Rapoport T (2007): Protein translocation across the eukaryotic endoplasmic reticulum and bacterial plasma membranes. Nature $\underline{450}$,663-9

Reuter S, Gupta SC, Chaturvedi MM, Aggarwal BB (2009): Oxidative stress, inflammation, and cancer: how are they linked? Free Radic Biol Med 49, 1603-16

Schächinger V, Zeiher AM (2000): Atherosclerosis-associated endothelial dysfunction. Z Kardiol 89 Suppl 9, IX/70-4

Schuldiner M, Metz J, Schmid V, Denic V, Rakwalska M, Schmitt H, Schwappach B, Weissman JS (2008): The GET complex mediates insertion of tail-anchored proteins into the ER membrane. Cell 134, 634-45

Selkoe DJ (2012): Preventing Alzheimer's Disease. Science 337, 1488-92

Stefer S, Reitz S, Wang F, Wild K, Pang YY, Schwarz D (2011): Structural basis for tailanchored membrane protein biogenesis by the Get3-receptor complex. Science $\underline{33}$, 758-62

Tran D, Russell H, Sutor S, van Deursen J, Bram R (2003): CAML Is Required for Efficient EGF Receptor Recycling. Dev Cell $\underline{5}, 245-56$

Vilardi F, Lorenz H, Dobberstein B (2011): WRB is the receptor for TRC40/Asna1mediated insertion of tail-anchored proteins into the ER membrane. J Cell Sci $\underline{124}$, $1301-7$

Vilardi F, Stephan M, Clancy A, Janshoff A, Schwappach B (2014): WRB and CAML are necessary and sufficient to mediate tail-anchored protein targeting to the ER membrane. PLoS One $\underline{9}$, e85033 
Voth W, Schick M, Gates S, Li S, Vilardi F, Gostimskaya I, Southworth DR, Schwappach B, Jakob U (2014): The protein targeting factor Get3 functions as ATP-independent chaperone under oxidative stress conditions. Mol Cell 56, 116-27

Wang F, Whynot A, Tung M, Denic V (2011): The mechanism of tail-anchored protein insertion into the ER membrane. Mol Cell $\underline{43}$, 738-50

Winterbourn CC (2015): Are free radicals involved in thiol-based redox signaling? Free Radic Biol Med $\underline{80}, 164-70$

Yamamoto Y, Sakisaka T (2012): Molecular machinery for insertion of tail-anchored membrane proteins into the endoplasmic reticulum membrane in mammalian cells. Mol Cell $\underline{48}, 387-97$

Yuan X, Yao J, Norris D, Tran D, Bram R, Chen G, Luscher B (2008): Calcium-modulating cyclophilin ligand regulates membrane trafficking of postsynaptic GABAA receptors. Mol Cell Neurosci 38, 277-89

Zane, Gundelach, Lindquist, Bram (2012): Essential Role for CAML in Follicular B Cell Survival and Homeostasis. J Immunol $\underline{188}$, 3009-18

Zhao W, Zhao T, Chen Y, Ahokas RA, Sun Y (2008): Oxidative stress mediates cardiac fibrosis by enhancing transforming growth factor-beta1 in hypertensive rats. Mol Cell Biochem 317, 43-50 


\section{Thanks to}

I want to express my biggest gratitude to Dr. Fabio Vilardi. He supervised me from day to day during my whole work period in the laboratory. He made this thesis possible with his sparkling support, advice and criticism.

I would also like to thank Prof. Dr. Blanche Schwappach-Pignataro for her big support and for giving me the opportunity to work in her lab. After all, my gratitude goes to the other members of the lab, who were always willing to help me or to answer my questions: Eric, Anne, Lena, Jhon, Marcus and Anna. 


\section{Curriculum vitae}

Family background: My name is Moritz Schaefer and I was born in Hameln, Germany at the $27^{\text {th }}$ of October in 1989. I currently live in Geismar Landstr. 49, 37083 Göttingen.

Education: In year 2009, I finished my school education at Viktoria-Luise-Gymnasium in Hameln (Abitur: Grade 1.4). Afterwards I fulfilled nine month of community service at the Institute for Solar Energy Research Hameln (ISFH). I continued my education at the faculty of medicine at the Georg-August-University Göttingen by studying human medicine since 2010 to the present. After accomplishing the first examination (preclinical studies) with grade 2.0 in 2012, I passed the second medical state examination with grade 2.0 in 2015.

Internships: During the time of my medical studies, I absolved internships in Göttingen, Berlin and Bangalore, India, which allowed me to look into the future work environment as a medical doctor. I could collect experience in the departments of surgery, internal medicine and family medicine. During my practical year I worked in the field of psychiatry for four months (Charité Campus Mitte, Berlin).

Further interests and languages: I speak German (native speaker), English (fluent in writing and speaking), French (advanced in writing and speaking) and Spanish (beginner in writing and speaking). Aside from medicine and natural sciences, I am very interested in exploring other cultures, music, psychology and politics. I am a passionate hobby photographer and electric bass player. As a sportsman I boulder and play football. 